\title{
PTR-MS measurements of non-methane volatile organic compounds during an intensive field campaign at the summit of Mount Tai, China, in June 2006
}

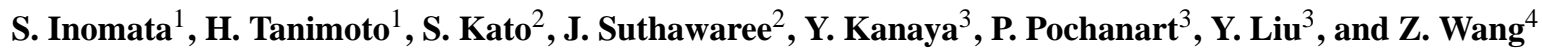 \\ ${ }^{1}$ National Institute for Environmental Studies, 16-2, Onogawa, Tsukuba, Ibaraki 305-8506, Japan \\ ${ }^{2}$ Tokyo Metropolitan University, Minami-osawa 1-1, Hachioji, Tokyo 192-0397, Japan \\ ${ }^{3}$ Research Institute for Global Change, Japan Agency for Marine-Earth Science and Technology, 3173-25, Showa-machi, \\ Yokohama, Kanagawa 236-0001, Japan \\ ${ }^{4}$ LAPC/NZC, Institute of Atmospheric Physics, Chinese Academy of Sciences, Beijing 10029, China
}

Received: 12 November 2009 - Published in Atmos. Chem. Phys. Discuss.: 11 December 2009

Revised: 8 July 2010 - Accepted: 19 July 2010 - Published: 3 August 2010

\begin{abstract}
Owing to recent industrialization, Central East China has become a significant source of air pollutants. To examine the processes controlling the chemistry and transport of tropospheric ozone, we performed on-line measurements of non-methane volatile organic compounds (NMVOCs) as part of an intensive field campaign at Mount Tai, China, in June 2006 (MTX2006), using proton transfer reaction mass spectrometry (PTR-MS). Temporal variations of NMVOCs were recorded in mass-scan mode from $m / z .17$ to $m / z 300$ during 12-30 June 2006. More than thirty kinds of NMVOCs were detected up to $m / z 160$, including alkenes, aromatics, alcohols, aldehydes, and ketones. In combination with non-methane hydrocarbon data obtained by a gas chromatography with flame ionization detection, it was found that oxygenated VOCs were the predominant NMVOCs. Diurnal variations depending mainly on local photochemistry were observed during 24-28 June. During the night of 12 June, we observed an episode of high NMVOCs concentrations attributed to the burning of agricultural biomass. The $\Delta$ NMVOCs/ $\triangle \mathrm{CO}$ ratios derived by PTR-MS measurements for this episode (with biomass burning (BB) plume) and during 16-23 June (without BB plume) are compared to emission ratios from various types of biomass burning as reviewed by Andreae and Merlet (2001) and to ratios recently measured by PTR-MS in tropical forests (Karl et al., 2007) and at urban sites (Warneke et al., 2007).
\end{abstract}

Correspondence to: S. Inomata (ino@nies.go.jp)

\section{Introduction}

Non-methane volatile organic compounds (NMVOCs), which are emitted from various sources into the atmosphere, play important roles in controlling air quality because they undergo gas-phase photochemical reactions leading to the formation of ozone and secondary aerosols (Atkinson, 2000; Finlayson-Pitts and Pitts, 2000). Hundreds of NMVOCs are present in urban areas where large quantities of NMVOCs are emitted by industry and other human activities (Lewis et al., 2000). The atmospheric lifetimes of NMVOCs range from a few hours to several tens of days (Warneck, 2000). Both ozone-formation potential, which is based on the incremental reactivity of NMVOCs, and yields of secondary organic aerosols depend on the precursor NMVOC (Carter and Atkinson, 1989; Seinfeld and Pandis, 1998). Therefore, simultaneous measurement of multiple NMVOCs, especially high temporal-resolution measurements of reactive NMVOCs, is required.

As one of the fastest growing countries in Asia, China is experiencing severe air pollution due to rapid urbanization and increased use of motorized vehicles. Investigating the variations of ambient NMVOCs, especially speciation in megacities and city clusters, has become increasingly important. Source characteristics of NMVOCs have been extensively investigated in the Pearl River Delta region (Chan et al., 2006; Tang et al., 2007, 2008; Liu et al., 2008; Zhang et al., 2008), in the Yangtze River Delta region (Geng et al., 2008; Geng et al., 2009), and in Beijing (Song et al., 2007; Xie et al., 2008; Liu et al., 2009; Shao et al., 2009). Barletta et al. (2005) measured methane

Published by Copernicus Publications on behalf of the European Geosciences Union. 
Table 1. Instruments for $\mathrm{O}_{3}, \mathrm{CO}$, and $\mathrm{NO}-\mathrm{NO}_{2}-\mathrm{NO}_{\mathrm{y}}$ monitor.

\begin{tabular}{lllll}
\hline Instrument name & Model number & Working principle & Species measured & Detection limit \\
\hline $\mathrm{O}_{3}$ Analyzer & Model 49C & Ultraviolet absorption & $\mathrm{O}_{3}$ & $1.0 \mathrm{ppbv}$ \\
$\mathrm{CO}$ Analyzer & Model 48C & Gas filter correlation & $\mathrm{CO}$ & $0.04 \mathrm{ppmv}$ \\
$\mathrm{NO}^{\mathrm{a} O} \mathrm{NO}_{\mathrm{x}}-\mathrm{NO}_{\mathrm{y}}$ Analyzer & Modified Model 42CTL & Molybdenum/Blue & $\mathrm{NO}$ & $0.1 \mathrm{ppbv}$ \\
& & ligh converters- & $\mathrm{NO}_{2}$ & $0.2 \mathrm{ppbv}$ \\
& & chemiluminesence & $\mathrm{NO}_{\mathrm{y}}$ & $0.2 \mathrm{ppbv}$ \\
\hline
\end{tabular}

a Thermo Environmental Instruments Inc.

and non-methane hydrocarbons (NMHCs), including alkanes, alkenes, and aromatics, in 43 Chinese cities and identified major sources of the hydrocarbons. Recently, Liu et al. (2009) and Shao et al. (2009) measured oxygenated VOCs (OVOCs) such as aldehydes, ketones, and alcohols, in addition to NMHCs, at an urban site in Beijing and found that the OVOCs were important components with respect to $\mathrm{OH}$ reactivity, accounting for approximately half of total $\mathrm{OH}$ loss rates due to NMVOCs.

Central East China (CEC) is regarded as one of the most significant source regions in the world for air pollutants such as nitrogen oxides $\left(\mathrm{NO}_{\mathrm{x}}\right)$, carbon monoxide (CO), and NMVOCs (Streets et al., 2003), and the presence of these pollutants results in high ozone $\left(\mathrm{O}_{3}\right)$ concentrations in the region. Pochanart et al. (in preparation, 2010) investigated the seasonal variation in $\mathrm{O}_{3}$ concentrations over CEC from observations at three mountain sites in the area: Mount Tai $\left(36.25^{\circ} \mathrm{N}, 117.10^{\circ} \mathrm{E}, 1534 \mathrm{~m}\right.$ a.s.1.), Mount Huang $\left(30.13^{\circ} \mathrm{N}, 118.16^{\circ} \mathrm{E}, 1841 \mathrm{~m}\right.$ a.s.1.), and Mount Hua $\left(34.48^{\circ} \mathrm{N}, 110.08^{\circ} \mathrm{E}, 2065 \mathrm{~m}\right.$ a.s.l.). They found that the maximum monthly $\mathrm{O}_{3}$ concentration $(>60$ part per billion by volume (ppbv)) occurred in May and June, and high hourly $\mathrm{O}_{3}$ levels ( $>120 \mathrm{ppbv}$ ) were often observed during this season from 2004 to 2006. Because these mountain stations are located at altitudes high enough to avoid the influence of local emissions, the air masses observed at each station can be considered as representative of the CEC region around the station (that is, within several hundred kilometers). Model simulations have been performed to examine the $\mathrm{O}_{3}$ seasonal cycle and high $\mathrm{O}_{3}$ episodes (Wang et al., 2006; Li et al., 2007; He et al., 2008; Li et al., 2008; Yamaji et al., 2008). It has been suggested that photochemical production is the primary cause for high $\mathrm{O}_{3}$ concentrations over this region. In situ observations of not only $\mathrm{O}_{3}$ and $\mathrm{CO}$ but also $\mathrm{O}_{3}$ precursors including NMVOCs would improve our understanding of photochemical processes and improve NMVOC emission inventories (Streets et al., 2003; Carmichael et al., 2003a, 2003b). However, the precursor concentrations in the model simulations have not been validated well through observations because there is limited knowledge on NMVOCs in the CEC region.
During the latter part (12-30 June 2006) of a campaign of the Mount Tai Experiment 2006 (MTX2006), we performed on-line measurements of ambient NMVOCs using a commercially available PTR-MS instrument at the observation station of Mount Tai. PTR-MS allows on-line measurements of NMVOCs at trace levels in air (Lindinger et al., 1998a, b; de Gouw and Warneke, 2007; Blake et al., 2009). We present here the speciation, quantities, and variation of NMVOCs measured by PTR-MS at the Mount Tai observation station. The NMVOC data obtained by means of PTR-MS, in combination with NMHC data obtained by gas chromatography with flame ionization detection (GC-FID) and gas chromatography-mass spectrometry (GC-MS) during the campaign (Suthawaree et al., 2010), can be expected to be useful for diagnosis of the $\mathrm{O}_{3}$ production regime $\left(\mathrm{NO}_{\mathrm{x}}{ }^{-}\right.$ limited vs. VOC-limited) over the CEC region (Kanaya et al., 2009) and for source identification (anthropogenic or biogenic).

\section{Experimental}

\subsection{MTX2006 campaign}

To examine the chemistry and transport related to $\mathrm{O}_{3}$ and aerosols over CEC, an intensive field campaign was implemented on the Mount Tai $\left(36.25^{\circ} \mathrm{N}, 117.10^{\circ} \mathrm{E}, 1534 \mathrm{~m}\right.$ a.s.l.) in June 2006 (MTX2006). The concentrations of surface $\mathrm{O}_{3}, \mathrm{CO}, \mathrm{CO}_{2}, \mathrm{NO}, \mathrm{NO}_{\mathrm{x}}, \mathrm{NO}_{\mathrm{y}}, \mathrm{NMVOCs}$, elemental carbon (EC), and organic carbon (OC); the chemical compositions of aerosols; $\mathrm{J}$ values; the tropospheric $\mathrm{NO}_{2}$ column; and meteorological parameters were measured ( $\mathrm{Li}$ et al., 2008; Kanaya et al., 2009; Akimoto, 2010).

As summarized in Table $1, \mathrm{O}_{3}$ and $\mathrm{CO}$ mixing ratios were measured with commercially available instruments (Thermo Environmental Instruments Inc., models $49 \mathrm{C}$ and $48 \mathrm{C}$ ), respectively (Pochanart et al., 2010). $\mathrm{NO}, \mathrm{NO}_{\mathrm{x}}$, and $\mathrm{NO}_{\mathrm{y}}$ were sequentially detected with a customized instrument based on a commercially available instrument (Thermo Environmental Instruments Inc., model 42 CTL). An air sample was passed through one of three gas lines: a line with a molybdenum converter, a line with a blue light (light-emitting diode) converter (Droplet Measurement Technology, USA), and a line 
Table 2. Pricipal parameters for PTR-MS operation.

\begin{tabular}{ll}
\hline Parameter & Value \\
\hline Overall drift voltage $\left(U_{\text {drift }}\right)$ & $400 \mathrm{~V}$ \\
Temperature at drift tube $\left(T_{\text {drift }}\right)$ & $105^{\circ} \mathrm{C}$ \\
Pressure at drift tube $\left(P_{\text {drift }}\right)$ & $2.1 \mathrm{mbar}$ \\
Length of drift tube $\left(L_{\text {drift }}\right)$ & $9.2 \mathrm{~cm}$ \\
Reaction time $(t)$ & $114 \mu \mathrm{s}$ \\
Field strength of drift tube $(E / N)^{\mathrm{a}}$ & $108 \mathrm{Td}$
\end{tabular}

${ }^{\text {a }} E$ is the electric field strength $\left(\mathrm{V} \mathrm{cm}^{-1}\right)$ and $N$ is the buffer gas number density (molecule $\mathrm{cm}^{-3}$ ).

$\mathrm{b} 1 \mathrm{Td}=10^{-17} \mathrm{~cm}^{2} \mathrm{~V}$ molecule ${ }^{-1}$.

without converters. The two converters were located at the entrance of the sampling tube, such that $\mathrm{NO}_{\mathrm{y}}$ and $\mathrm{NO}_{2}$ were converted to NO, a relatively inert molecule, early in the inlet line with minimum loss. The efficiency of the conversion of $\mathrm{NO}_{2}$ to $\mathrm{NO}$ by the blue light converter during the campaign was $50 \%$. The sensitivity to NO was determined with premixed NO/ $\mathrm{N}_{2}$ gas (2.004 ppmv, Taiyo Nippon Sanso Corporation). The sensitivity agreed with that determined with a cylinder with NIST-traceability to within $2 \%$.

\subsection{PTR-MS set-up at Mount Tai}

A commercially available PTR-MS instrument was used for this work (Ionicon Analytik GmbH, Innsbruck, Austria) (Lindinger et al., 1998a, b; Inomata et al., 2008). Briefly, reagent ions, $\mathrm{H}_{3} \mathrm{O}^{+}$, were produced from a pure water vapor flow in a hollow cathode discharge ion source. The sample air was introduced from the sample port beneath the ion source into the drift tube, where a homogeneous electric field was established and trace gases such as VOCs in the sample air were ionized by proton transfer reactions:

$\mathrm{H}_{3} \mathrm{O}^{+}+\mathrm{VOC} \rightarrow \mathrm{VOCH}^{+}+\mathrm{H}_{2} \mathrm{O}$

A fraction of the reagent ions $\left(\mathrm{H}_{3} \mathrm{O}^{+}\right)$and product ions $\left(\mathrm{VOCH}^{+}\right)$was extracted through a small orifice into a quadrupole mass spectrometer. The ions were detected by a secondary electron multiplier for ion pulse counting. The mass dependence of the transmission efficiency of the quadrupole mass spectrometer was calibrated by the manufacturer. The principal parameters for the PTR-MS operation were listed in Table 2. The field strength of the drift tube was set to $108 \mathrm{Td}$ to minimize fragmentation of the detected VOCs. The count rate of the reagent ion $\left(\mathrm{H}_{3} \mathrm{O}^{+}\right)$was typically $1 \times 10^{7} \mathrm{cps}$ during the observation. Data were continuously recorded using the PTR-MS instrument's scan mode (from $m / z, 17$ to $m / z, 300$ with 0.1-s data collection at each step).

The PTR-MS instrument was housed in a room on the ground floor of the observation station located at the summit of Mount Tai. Mount Tai is an isolated single mountain in the
North China plain. The summit overlooks the city of Tai'an (population: 500000 ), $10 \mathrm{~km}$ to the south. The city of Ji'nan (capital of Shandong province, population: 2.1 million) is situated $60 \mathrm{~km}$ to the north. There are many tourists on the mountain in the summer months (June-September); consequently, local emissions from small restaurants and temples are sometimes significant pollution sources. (Gao et al., 2005). The inlet for ambient air sampling was located approximately $10 \mathrm{~m}$ above the ground. A 1/4" Teflon line ( $4.0 \mathrm{~mm}$ ID, $\sim 15 \mathrm{~m}$ length) was used as a sampling line. The ambient air was pumped with a diaphragm pump at flow rate of $2 \mathrm{~L} \mathrm{~min}^{-1}$, with an estimated residence time of $6 \mathrm{~s}$ in the flow tube. An in-line particulate filter was used to prevent particles from entering the instrument. Zero-air generated by a zero-air supply (Thermo Environmental Instruments Inc. (TEI), Model 111) was sampled into the PTR-MS instrument for the purpose of determining the background signal for each $m / z$. Twice daily (11:00-11:30 CST (China Standard Time) and 23:00-23:30 CST), we introduced standard gas mixtures containing propene, acetaldehyde, acetone, isoprene, benzene, toluene, and $p$-xylene at mixing ratios of $10.5 \mathrm{ppbv}$ into the PTR-MS instrument to check the stability of the detection sensitivities for seven VOCs during the observation; the standard gas mixtures were produced by dynamic dilution of a seven-VOC premixed standard gas (5 parts per million by volume (ppmv)) with zero-air. Typically, ambient air was sampled for $1.5 \mathrm{~h}$, and then background signals were measured for $0.5 \mathrm{~h}$.

\subsection{Detection sensitivity and humidity dependence for NMVOCs}

The detection sensitivity and its humidity dependence for eleven VOCs (formaldehyde, methanol, acetonitrile, propene, acetaldehyde, ethanol, acetone, isoprene, benzene, toluene, and $p$-xylene) were determined in the laboratory. The method to determine them was already described for formaldehyde in Inomata et al. (2008). For other VOCs, VOCs at $10-100$ ppbv mixing ratios was produced by a dynamic dilution of the standard gas with zero air generated by a zero air supply (TEI, Model 111). The dynamic dilution system was custom-built and consisted of two mass flow controllers (AERA, FC-795C @ $10 \mathrm{sccm}$ (air) and FC-795C @ $5 \mathrm{slm}$ (air)). The mass flow controllers were calibrated by film flow meters (Agilent Technologies, Humonics Optiflow 420 and HORIBASTEC, VP-40, respectively). The uncertainty of the derived concentration was typically $3 \%$. To vary the humidity in the sample, a humidity controller (SHINYEI, SRG-1R-10) was connected to the line carrying zero air. The water vapor concentration of the moist air was estimated using an optical chilled mirror hygrometer (General Eastern, 1311DR-SR) between the humidity controller and the PTRMS. The humidity dependence was examined in the range of 0 to $25 \mathrm{mmol} / \mathrm{mol}$ for the absolute water vapor concentrations. The results are summarized in Table 3, along with the 
Table 3. Detection sensitivity, its humidity dependence, and detection limit for eleven VOCs.

\begin{tabular}{lllll}
\hline NMVOC & $m / z$ & Proton affinity $^{\mathrm{a}}(\mathrm{kJ} / \mathrm{mol})$ & Detection sensitivity $^{\mathrm{b}}(\mathrm{ncps} / \mathrm{ppbv})$ & Detection limit $^{\mathrm{c}}(\mathrm{ppbv})$ \\
\hline Formaldehyde & 31 & 713 & ${ }^{(169 \pm 32)} \mathrm{d}$ & $0.15-0.34$ \\
Methanol & 33 & 754 & $10.6 \pm 0.4$ & 0.30 \\
Acetonitrile & 42 & 779 & $12.8 \pm 0.3$ & 0.01 \\
Propene & 43 & 752 & $4.79 \pm 0.29$ & 0.26 \\
Acetaldehyde & 45 & 769 & $(13.8 \pm 0.9)+(0.093 \pm 0.024)\left[\mathrm{H}_{2} \mathrm{O}\right]_{\text {sample }}$ & $0.12-0.14$ \\
Ethanol & 47 & 776 & $(1.56 \pm 0.11)+(0.025 \pm 0.003)\left[\mathrm{H}_{2} \mathrm{O}\right]_{\text {sample }}$ & $1.6-2.3$ \\
Acetone & 59 & 812 & $(13.9 \pm 0.9)+(0.119 \pm 0.029)\left[\mathrm{H}_{2} \mathrm{O}\right]_{\text {sample }}$ & $0.06-0.07$ \\
Isoprene & 69 & 826 & $6.53 \pm 0.34$ & 0.11 \\
Benzene & 79 & 750 & $7.07 \pm 0.38$ & 0.05 \\
Toluene & 93 & 784 & $7.94 \pm 0.44$ & 0.16 \\
$p$-Xylene & 107 & 794 & $7.56 \pm 0.43$ & 0.15 \\
\hline
\end{tabular}

a Hunter and Lias, 1998

b Detection sensitivity normalized to a $\mathrm{H}_{3} \mathrm{O}^{+}$intensity of $10^{6} \mathrm{cps} .\left[\mathrm{H}_{2} \mathrm{O}\right]_{\text {sample }}$ represents the water vapor concentration in the sample (mmol/mol). Error limits represent $95 \%$ confidence levels by $t$-test.

${ }^{\mathrm{c}}$ Detection limit at $S / N=2$ for a typical 10 -s integration $(0.1 \mathrm{~s} \times 100$ scans over $1 \mathrm{~h})$.

${ }^{\mathrm{d}}$ Inomata et al., 2008.

detection limits for these VOCs. The detection sensitivity of a VOC was defined as the signal intensity for $\mathrm{VOCH}^{+}$normalized to a $\mathrm{H}_{3} \mathrm{O}^{+}$intensity of $10^{6}$ counts per second (cps) when $1 \mathrm{ppbv}$ of the VOC was present in the sample, and the unit for the sensitivity is normalized cps (ncps)/ppbv. No significant humidity dependence of the background signals at the masses listed in Table 3 was found. As an example, the humidity dependence of the normalized signal intensity at $m / z 69$ with isoprene (22 ppbv) and without isoprene is shown in Figs. 1S of the supplement material. In Fig. $2 \mathrm{~S}$ of the supplement material, temporal variations of the background signals at $m / z 69$ during the field measurements are shown as 10-min averages, based on measurements of dry zero-air from a zero-air supply (TEI, model 111). Although the observed background signals might have decreasing trend over the course of the measurement period, we think that there is no problem in the efficiency of the zero-air supply in removing VOCs.

The detection sensitivities under dry conditions ranged from $\sim 5$ to $\sim 14 \mathrm{ncps} / \mathrm{ppbv}$ for all the compounds except ethanol (1.56 ncps/ppbv). Because the detection sensitivity calculated using a typical ion-molecule rate constant for Reaction (R1) $\left(2 \times 10^{-9} \mathrm{~cm}^{3}\right.$ molecule $\left.{ }^{-1} \mathrm{~s}^{-1}\right)$ is 9 ncps/ppbv, the differences between the detection sensitivities can be explained in terms of the difference between the rate constants $\left((1.5-3.3) \times 10^{-9} \mathrm{~cm}^{3}\right.$ molecule ${ }^{-1} \mathrm{~s}^{-1}$ ) (Zhao and Zhang, 2004). The extremely low detection sensitivity for ethanol was caused by the presence of the channel reproducing $\mathrm{H}_{3} \mathrm{O}^{+}$(Inomata and Tanimoto, 2009).

With regard to humidity dependence, there are three types; that is, the detection sensitivity decreases, increases, or does not change with increasing humidity. The detection sensitivity for formaldehyde reportedly decreases with increasing humidity, owing to the reverse of Reaction (R1) because the exothermicity of Reaction (R1) is small for formaldehyde (Inomata et al., 2008). Polar molecules react with $\mathrm{H}_{3} \mathrm{O}^{+} \mathrm{H}_{2} \mathrm{O}$ to produce $\mathrm{VOCH}^{+}$ions (Reaction (R2); Smith and Španel, 2005).

$\mathrm{H}_{3} \mathrm{O}^{+} \mathrm{H}_{2} \mathrm{O}+\mathrm{VOC} \rightarrow \mathrm{VOCH}^{+}+2 \mathrm{H}_{2} \mathrm{O}$

The abundance of $\mathrm{H}_{3} \mathrm{O}^{+} \mathrm{H}_{2} \mathrm{O}$ increases under humidified conditions, and the signals for $\mathrm{VOCH}^{+}$ions produced by Reaction (R2) are added to the signals for $\mathrm{VOCH}^{+}$ions produced by Reaction (R1). Therefore, the detection sensitivities for acetone, acetaldehyde, and ethanol showed a positive dependence on humidity. Because the proton affinity of methanol is small relative to the values for acetone, acetaldehyde, and ethanol, the contribution of Reaction (R2) is negligible for methanol, so that no humidity dependence of the detection sensitivity for methanol was probably observed.

It was recently reported that there is little humidity dependence of the sensitivity for benzene and toluene by Jobson and McCoskey (2010) and Vlasenko et al. (2010), which are in good agreement with the present results. In contrast, these results are different from that by Warneke et al. (2001) where a significant decrease of the sensitivity for benzene and toluene were found with an increase of the humidity. Jobson and McCoskey (2010) suggested that any change in the normalized sensitivity of benzene would indicate ion sampling artifacts in the vacuum interface between the drift tube and quadrupole if benzene does not react with $\mathrm{H}_{3} \mathrm{O}^{+} \cdot \mathrm{H}_{2} \mathrm{O}$ in the PTR-MS. The present result indicates that our PTR-MS system has no ion sampling artifact and that the calibrations were successful.

One of the main weaknesses of PTR-MS is its reliance solely on mass spectrometry for discriminating between 
molecules, which means that isobaric species cannot be distinguished. The NMVOCs listed in Table 3 were chosen as representative species that give an ion signal at each $\mathrm{m} / z$; for example, methanol gives an ion signal at $m / z$ 33. For the mass numbers listed in the table, we converted measured ion signals to mixing ratios by using the corresponding detection sensitivities in this work. However, we do not discuss the ion signals at $m / z 43$ and $m / z 47$ in this paper, because the detection sensitivity for ethanol was extremely low compared to that of other species and because many VOCs can give ion signals at $m / z 43$ (Warneke et al., 2003).

For other mass numbers, volume mixing ratios (VMRs) were calculated with the following equation:

$$
(\mathrm{VMR})=\frac{(\text { Signal }) \cdot 1 E 9 \cdot 1013 \cdot 22400 \cdot\left(273.15+T_{\text {drift }}\right)}{k \cdot t \cdot(\mathrm{M} 21) \cdot 500 \cdot P_{\text {drift }} \cdot 6.022 E 23 \cdot 273.15}
$$

where (Signal) and (M21) are the signal intensities of $\mathrm{VOCH}^{+}$and $\mathrm{H}_{3}^{18} \mathrm{O}^{+}$, respectively; and $k$ and $t$ are the rate constant and the reaction time for the protonation reaction. The rate constant used was $2.0 \times 10^{-9} \mathrm{~cm}^{3}$ molecule ${ }^{-1} \mathrm{~s}^{-1}$. The uncertainty in Eq. (1) is thought to be approximately $\pm 50 \%$, according to the differences between the calibrated and calculated detection sensitivities for the VOCs listed in Table 3 except ethanol. Detection limits at $S / N=2$ were estimated to be $0.01-0.08 \mathrm{ppbv}$ for a typical 10 -s integration $(0.1 \mathrm{~s} \times 100$ scans over a period of $1 \mathrm{~h})$.

Standard gases of $\mathrm{HCHO} / \mathrm{N}_{2}$ (1.02 ppmv, Takachiho), $\mathrm{CH}_{3} \mathrm{OH} / \mathrm{N}_{2}$ (10.8 ppmv, Takachiho), $\mathrm{C}_{2} \mathrm{H}_{5} \mathrm{OH} / \mathrm{N}_{2}$ (9.56 ppmv, Takachiho), and $\mathrm{CH}_{3} \mathrm{CN} / \mathrm{N}_{2}$ (9.98 ppmv, Japan Fine Products) and a seven-VOC premixed standard gas containing propene (4.92 ppmv), acetaldehyde (5.07 ppmv), acetone (5.05 ppmv), isoprene (4.98 ppmv), benzene (4.97 ppmv), toluene $(5.16 \mathrm{ppmv})$, and $p$-xylene $(4.90 \mathrm{ppmv})$ balanced with $\mathrm{N}_{2}$ (Japan Fine Products) were used as received.

\subsection{Measurements by GC-FID}

During 2-28 June, ambient air was stored for the VOC analyses. The air was compressed with a PFA (perfluoroalkoxy polymer resin) bellows pump into a canister whose inner surface was coated with fused silica to stabilize the trace components for longer storage periods. The ambient air was typically sampled once per day (in the daytime) with a sampling duration of $2 \mathrm{~min}$, and the sample canisters were analyzed after the campaign by GC-FID (HP6890). Data of ten alkanes, acetylene, four alkenes, six aromatics, isoprene, and 3 halocarbons, along with detailed information about the canister sampling and analysis, are presented elsewhere (Suthawaree et al., 2010). PTR-MS-derived concentrations for isoprene (ion signal at $m / z 69$, referred to as M69), benzene (M79), toluene (M93), and $\mathrm{C}_{8}$ benzenes (M107) were compared with those obtained by GC-FID (Sect. 3.2).

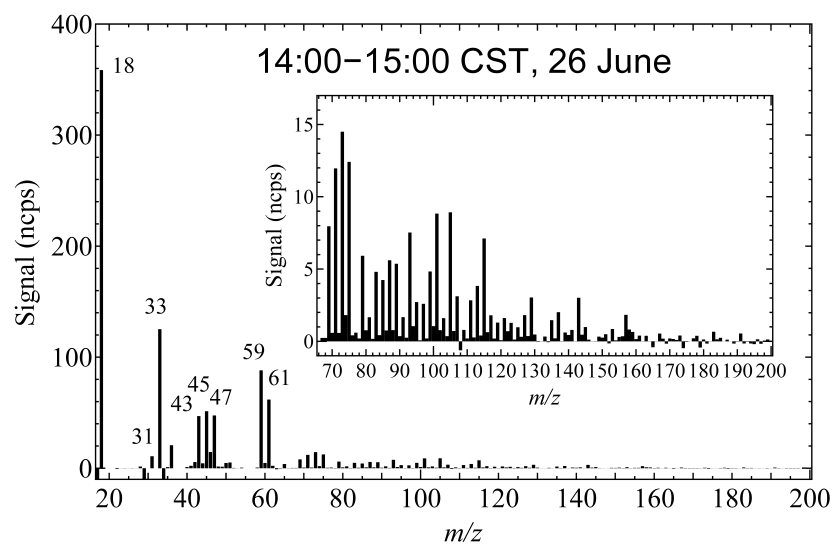

Fig. 1. An hourly averaged mass spectrum obtained on 26 June from 14:00 to 15:00 CST. Ion signals at $m / z, 19-21,37-39,55$ 57,30 , and 32 were masked because these ion signals are largely scattered as a result of a subtraction of the background spectrum.

\section{Results and discussion}

\subsection{PTR mass spectrum}

More than thirty kinds of NMVOCs were detected at the summit of Mount Tai by means of PTR-MS. Figure 1 shows an example of an hourly averaged mass spectrum obtained in daytime (14:00-15:00 CST on 26 June). Many protonated molecules were detected at odd $\mathrm{m} / \mathrm{z}$ values up to $m / z 160$. Strong peaks were attributable to ammonia (M18), formaldehyde (M31), methanol (M33), propene and/or a fragment from propanol, etc. (M43), acetaldehyde (M45), formic acid and/or ethanol (M47), acetone and/or propanal (M59), and acetic acid, methyl formate, and/or a fragment from acetates (M61). In addition, ion signals for a series of aromatics (M79, M93, M107, M121, and M135), ketones/aldehydes $\left(\mathrm{C}_{n} \mathrm{H}_{2 n} \mathrm{O}\right.$, M73, M87, M101, M115, M129, M143, and M157), and acids/formates/acetates/hydroxyketones/hydroxyaldehydes $\left(\mathrm{C}_{n} \mathrm{H}_{2 n} \mathrm{O}_{2}, \mathrm{M} 75\right.$, M89, M103, and M117) were observed. In fact, $n$-nonanal $\left(\mathrm{CH}_{3}\left(\mathrm{CH}_{2}\right)_{7} \mathrm{CHO}\right.$, mass 142) and n-decanal $\left(\mathrm{CH}_{3}\left(\mathrm{CH}_{2}\right)_{8} \mathrm{CHO}\right.$, mass 156$)$ were measured during the campaign by means of sampling with an $\mathrm{O}$ benzylhydroxylamine-impregnated filter and subsequent GC-FID and GC-MS analyses (Okuzawa et al., 2010). Ion signals attributed to biogenic VOCs such as isoprene (M69) were also observed.

The ion signal at $m / z 71$ can be attributed to protonated pentenes, but the mixing ratio of total pentenes (that is, the sum of 1-pentene, cis-2-pentene, trans-2-pentene, 3-methyl1-butene, and 2-methyl-2-butene) was 11 parts per trillion by volume (pptv), as determined by GC-FID analysis of a sample collected at 14:44 CST on 26 June (TS30) (Suthawaree et al., 2010). This mixing ratio is lower than the PTRMS detection limits in the present work, so we attributed the 

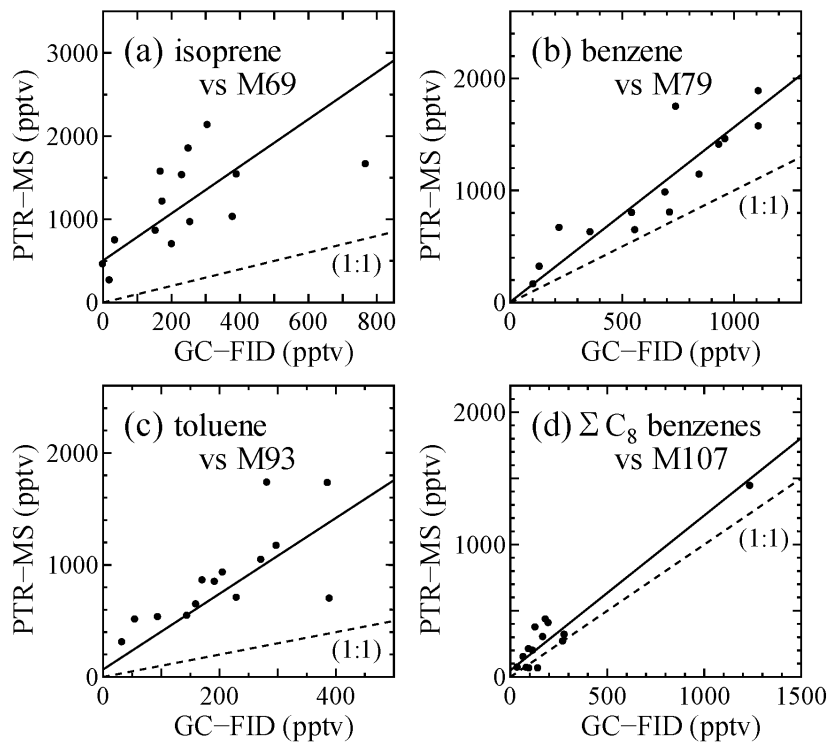

Fig. 2. Comparison of PTR-MS data with GC-FID data for (a) isoprene, (b) benzene, (c) toluene, and (d) $\Sigma \mathrm{C}_{8}$ benzenes; 10-min averaged PTR-MS data are used for the comparison. The best-fit lines obtained by RMA regression and $y=x$ lines are indicated by solid lines and dashed lines, respectively. The best-fit line: (a) $y=(2.8 \pm 1.4) x+(505 \pm 403), r^{2}=0.36$, (b) $y=(1.6 \pm 0.4) x+$ $(6 \pm 306), r^{2}=0.82$, (c) $y=(3.4 \pm 1.7) x+(67 \pm 393), r^{2}=0.53$, (d) $y=(1.2 \pm 0.2) x+(50 \pm 78), r^{2}=0.92$.

ion signals at $m / z 71,85,99,113$, and 127 not to alkenes but predominantly to OVOCs such as unsaturated aldehydes/ketones $\left(\mathrm{C}_{n} \mathrm{H}_{2 n-2} \mathrm{O}\right)$.

\subsection{Comparison between PTR-MS- and GC-FID-derived concentrations}

PTR-MS-derived concentrations for isoprene (calibrated), benzene (calibrated), toluene (calibrated), and $\Sigma \mathrm{C}_{8}$ benzenes (calibrated against $p$-xylene) were determined from the ion signals at $m / z 69,79,93$, and 107 , respectively. The mixing ratios of isoprene, benzene, toluene, and $\Sigma \mathrm{C}_{8}$ benzenes ( $m$ - and $p$-xylenes, $o$-xylene, and ethylbenzene) were measured independently by means of GC-FID (Suthawaree et al., 2010). Scatterplots of fourteen mixing ratios obtained by GC-FID versus the corresponding mixing ratios obtained by PTR-MS are shown in Fig. 2, along with best-fit lines determined by means of reduced-major-axis (RMA) regression (Ayers, 2001). The GC-FID mixing ratios of $\Sigma \mathrm{C}_{8}$ benzenes were obtained from the sum of the ratios of $m$ - and $p$-xylenes, $o$-xylene, and ethylbenzene.

Reasonable agreement was observed for $\Sigma \mathrm{C}_{8}$ benzenes (Fig. 2d). Although the slope for benzene was slightly greater than 1 (Fig. 2b), the PTR-MS-derived concentrations were proportional to those derived by GC-FID. For M79, there may have been interference from higher aromatics such as ethyl- and propylbenzenes (de Gouw and Warneke, 2007).
For isoprene and toluene (Fig. 2a and c), the slopes obtained by RMA regression were substantially greater than 1, which suggests that the PTR-MS-derived concentrations were overestimated for these species, probably owing to interference from other species, including fragment ions. In addition to having a slope greater than 1, the isoprene plot had a high offset. Biogenic VOCs such as 2- and 3-methyl butanal, 1-penten-3-ol, and 2-methyl-3-buten-2-ol are thought to contribute to the ion signal at M69 (de Gouw and Warneke, 2007). In addition, we have found that higher-molecularweight aldehydes such as 1-decanal generate fragment ions at M69. Thus, the large slope may have been due the fragment ions from these VOCs. The high offset was probably due to the interference from other NMVOCs such as furan, substantial concentrations of which have been observed in laboratory measurements of emissions from biomass burning (Christian et al., 2004).

For toluene, the PTR-MS-derived concentrations were also proportional to those derived by GC-FID, but the slope of the best-fit line (3.4 \pm 1.7$)$ was far from 1 (Fig. 2c). There have been no reports of interfering species for M93, and the reason for the high slope requires further investigation.

de Gouw et al. (2003) showed good agreement between PTR-MS- derived and GC-MS-derived concentrations for a variety of VOCs including methanol, acetonitrile, acetaldehyde, acetone, isoprene, methylvinylketone (MVK) and methacrolein (MACR), methylethylketone (MEK), benzene, toluene, $\mathrm{C}_{8}$ aromatics, $\mathrm{C}_{9}$ aromatics, and monoterpenes. We expected that such agreement would be obtained. However, there was significant discrepancy for toluene and isoprene. We think that the number of samples for the intercomparison was not enough due to limited availability of canisters for the GC-FID. We will build on-site GC-FID/MS system by which ambient air is directly analyzed, and will be able to compare GC-FID/MS with PTR-MS data as de Gouw et al. (2003). For the purposes of this paper, we corrected the PTR-MS-derived concentrations for isoprene (M69), benzene (M79), and toluene (M93) using the corresponding best-fit lines, and the corrected values are designated as M69*, M79*, and M93*, respectively.

\subsection{Diurnal variations during 24-28 June}

Substantial diurnal variations mainly due to local photochemistry were observed during 24-28 June for formaldehyde (Inomata et al., 2008). Hourly mean PTR-MS data for multiple NMVOCs were further averaged for five days (2428 June) and are displayed in Fig. 3, along with meteorological parameters (temperature and atmospheric pressure) and $\mathrm{O}_{3}, \mathrm{CO}, \mathrm{NO}_{\mathrm{x}}$, and $\mathrm{NO}_{\mathrm{y}}$ mixing ratios. It should be noted that the summit of Mount Tai is sometimes located in the free troposphere owing to downward movement of the planetary boundary layer (PBL) at night (Fu et al., 2009; Suthawaree et al., 2010). 

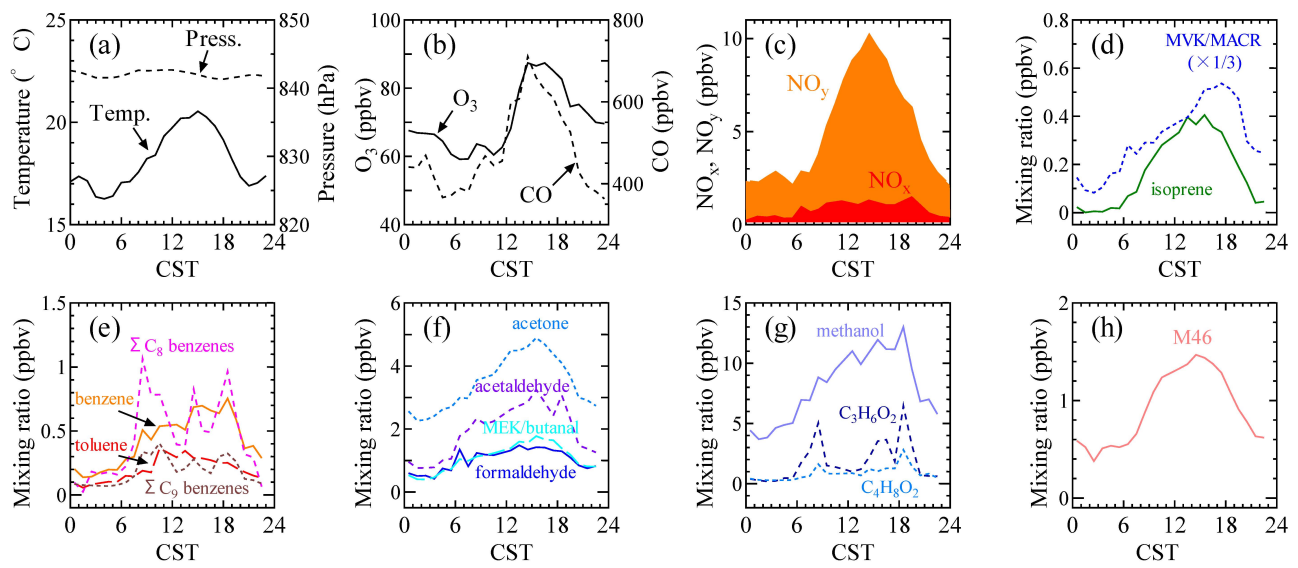

Fig. 3. Diurnal variations of temperature, atmospheric pressure, and mixing ratios of $\mathrm{O}_{3}, \mathrm{CO}, \mathrm{NO}_{\mathrm{x}}, \mathrm{NO}_{\mathrm{y}}$, and several $\mathrm{NMVOCs}$ averaged during 24-28 June.

Averaged diurnal variations of $\mathrm{NO}_{\mathrm{x}}$ and $\mathrm{NO}_{\mathrm{y}}$ are shown in Fig. 3c. The mixing ratios of $\mathrm{NO}_{\mathrm{y}}$ started increasing at around 08:00 CST and reached a maximum at around 14:00 CST, and then gradually decreased toward night. Since the fraction of $\mathrm{NO}_{\mathrm{x}}$ in $\mathrm{NO}_{\mathrm{y}}$ was small as shown in the figure, the temporal variation of $\mathrm{NO}_{\mathrm{z}}\left(=\mathrm{NO}_{\mathrm{y}}-\mathrm{NO}_{\mathrm{x}}\right)$, which is explicitly the secondary product, was very similar to that of $\mathrm{O}_{3}$. The net $\mathrm{O}_{3}$ production rate was estimated by a box model to be $51 \mathrm{ppbv} \mathrm{d}^{-1}$ during the $16-30$ June period (Kanaya et al., 2009). This rate is large enough to explain the observed $\mathrm{O}_{3}$ increase shown in Fig. 3(b) ( $230 \mathrm{ppbv})$. These suggest large influence from local photochemistry on the observed diurnal $\mathrm{O}_{3}$ profile. On the other hand, it is interesting to note that the mixing ratios of not only $\mathrm{O}_{3}$ but also $\mathrm{CO}$ started increasing in the early morning and reached a maximum in the early afternoon (Fig. 3b). This suggests a substantial role of the PBL development in shaping the profiles of these species. Hence a part of the daytime increase in secondary products like $\mathrm{O}_{3}$ and $\mathrm{NO}_{z}$, are likely caused by the development of PBL. $\mathrm{O}_{3}$ itself and/or the $\mathrm{O}_{3}$ precursors were likely transported from the ground surface to the top of Mt. Tai, resulting in the increase of $\mathrm{O}_{3}$ as seen in Fig. 3b.

The emissions of biogenic VOCs, isoprene (M69*), are controlled mainly by sunlight (Finlayson-Pitts and Pitts, 2000). The diurnal variation with the daytime maximum was observed for isoprene and the mixing ratio was almost zero at night (Fig. 3d). The mixing ratio for M71 attributed to MVK and MACR, which are thought to be photochemical products of isoprene, peaked late in the afternoon, after the peak for isoprene (Fig. 3d). Figure 3e shows the diurnal variations of the aromatics, which were irregular. Similar behaviors were observed for methanol (M33) and $\mathrm{C}_{3} \mathrm{H}_{6} \mathrm{O}_{2}$ (e.g., methyl acetate and hydroxyacetone; $\mathrm{M} 75$ ) and $\mathrm{C}_{3} \mathrm{H}_{6} \mathrm{O}_{2}$ (e.g., ethyl acetate; M89) (Fig. 3g). The diurnal variations of aldehydes/ketones showed behaviors between those of primarily emitted species (e.g., $\mathrm{NO}_{\mathrm{x}}$ ) and those of photochem- ically produced species (e.g., $\mathrm{NO}_{\mathrm{z}}$ ). For example, the peak at M31 in the morning was probably due to primary emission of formaldehyde (Fig. 3f). The temporal profile of M46 (Fig. 3h) was somewhat consistent with that of $\mathrm{NO}_{\mathrm{z}}$, which indicates that the species detected at M46 were produced mainly by photochemical processes.

\subsection{Inter-diurnal variations of NMVOCs}

\subsubsection{NMHCs}

Temporal variations of mixing ratios for isoprene and aromatics (benzene, toluene, and $\Sigma \mathrm{C}_{8^{-}}, \Sigma \mathrm{C}_{9^{-}}$, and $\Sigma \mathrm{C}_{10}$ benzenes) are shown in Fig. 4. In the figure, mixing ratios of isoprene, benzene, and toluene were corrected on the basis of data obtained by GC-FID, as indicated by the asterisks. Data for M69 during an episode of high NMVOC concentrations on the night of 12 June, when a biomass burning plume was observed (see Sect. 3.5), were masked because the M69 signal also increased, probably owing to furan (Christian et al., 2004). For isoprene, diurnal variations, with a daytime maximum and nighttime minimum, were clearly observed during the entire period. In particular, the mixing ratios of isoprene were almost zero at night (Fig. 4a).

As shown in Fig. 4b, the mixing ratio of benzene was usually higher than the ratio of toluene. Averaged, standard deviation, median, minimum, and maximum mixing ratios for benzene and toluene were summarized in Table 4. Suthawaree et al. (2010) suggested from the enhancement ratios of benzene and toluene to acetylene by GC-FID that the observation site was greatly affected by emissions from stationary sources rather than vehicular emissions. Sharp peaks were observed in common for $\Sigma \mathrm{C}_{8}$ benzenes (xylenes and ethylbenzene), $\Sigma \mathrm{C}_{9}$ benzenes (trimethylbenzenes methylethylbenzenes, and propylbenzenes), and $\Sigma \mathrm{C}_{10}$ benzenes (e.g., tetramethylbenzenes). 
Table 4. Averaged, standard deviation (SD), median, minimum, and maximum mixing ratios (ppbv) of NMVOCs during $12-30$ June $2006 .{ }^{\mathrm{a}}$

\begin{tabular}{llllll}
\hline NMVOC & Average & SD & Median & Minimum & Maximum \\
\hline Formaldehyde (M31) & 1.6 & 1.6 & 1.2 & LDL $^{\mathrm{b}}$ & 16.0 \\
Methanol (M33) & 10.0 & 4.7 & 9.4 & 0.9 & 34.8 \\
Acetonitrile (M42) & 0.7 & 0.6 & 0.6 & 0.1 & 6.6 \\
Acetaldehyde (M45) & 2.8 & 2.6 & 2.3 & 0.4 & 25.8 \\
Acetone (M59) & 4.5 & 1.7 & 4.2 & 1.7 & 13.2 \\
Benzene (M79*) & 0.6 & 0.4 & 0.5 & LDL $^{b}$ & 2.7 \\
Toluene (M93*) & 0.2 & 0.1 & 0.2 & LDL $^{b}$ & 1.2 \\
\hline
\end{tabular}

${ }^{\text {a }}$ Hourly averaged PTR-MS data were used.

${ }^{\mathrm{b}}$ Lower than detection limit.

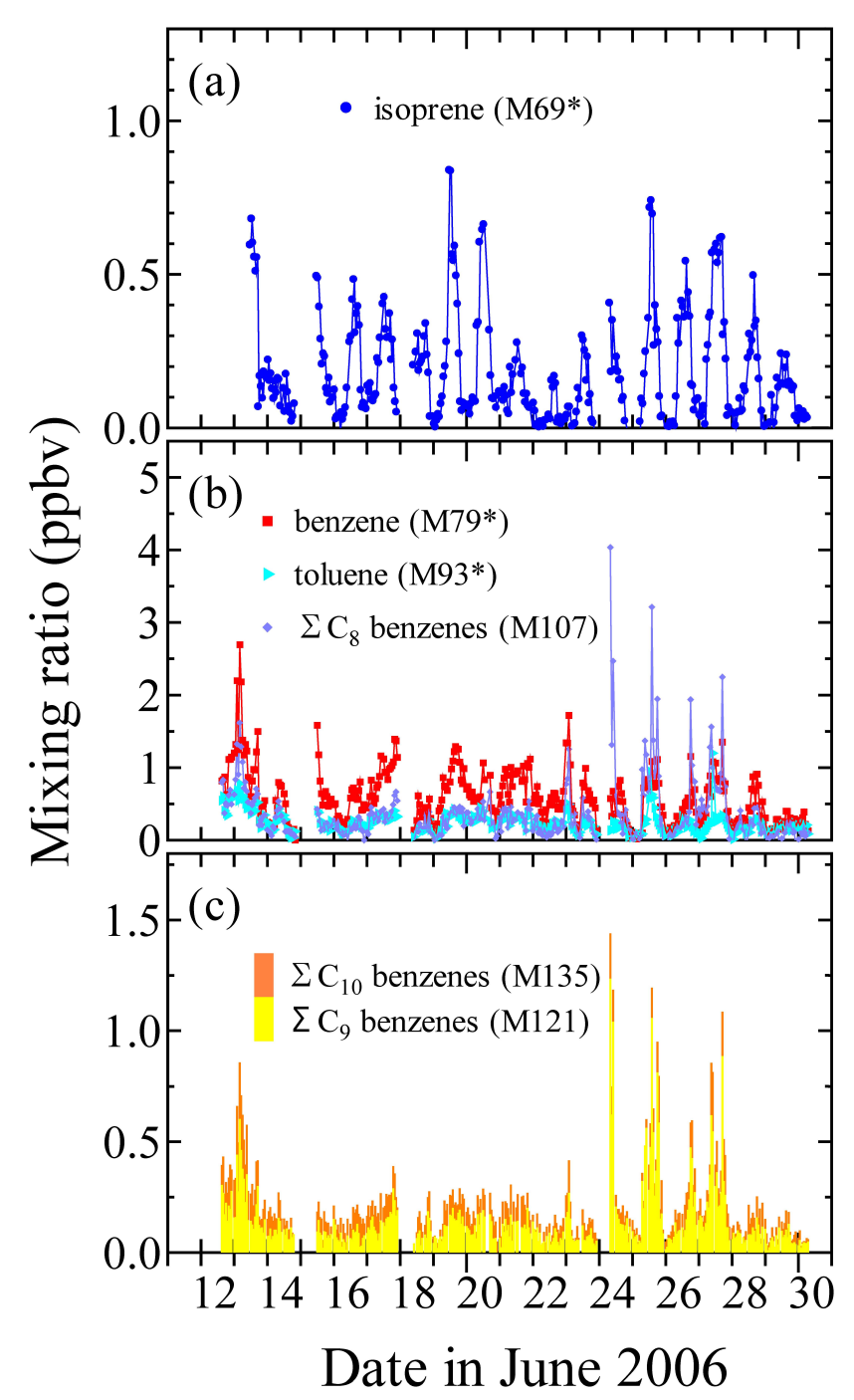

Fig. 4. Temporal variations of mixing ratios for hydrocarbons: (a) isoprene and (b) and (c) aromatics. Hourly averaged PTR-MS data are shown. Asterisks indicate mixing ratios corrected by GC-FID data (see text).
Overall mean concentrations for these hydrocarbons over the entire period were $\sim 2$ ppbv. According to the GC-FID results, overall mean concentrations of NMHCs including saturated hydrocarbons (25 species), unsaturated hydrocarbons (20 species), and aromatics (7 species) were 9.1 ppbv in daytime and $2.4 \mathrm{ppbv}$ at night (average $5.8 \mathrm{ppbv}$ ) during 12-30 June (Suthawaree et al., 2010). These values indicate that approximately $35 \%$ of the NMHCs were observed by PTRMS. The major NMHC components were ethane, propane, ethene, and acetylene, which cannot be detected by PTR-MS, because their proton affinities are lower than the proton affinity of $\mathrm{H}_{2} \mathrm{O}$.

\subsubsection{OVOCs}

The temporal variations of the mixing ratios of OVOCs such as ketones/aldehydes, methanol, and $\mathrm{C}_{n} \mathrm{H}_{2 n} \mathrm{O}_{2}$ (acids/formates/acetates/hydroxyketones/hydroxyaldehydes) are shown in Fig. 5. Averaged, standard deviation, median, minimum, and maximum mixing ratios for formaldehyde, acetaldehyde, acetone, and methanol were summarized in Table 4. An episode of high NMVOCs concentrations was observed during the night of 12 June. As described later (Sect. 3.5), mixing ratios for OVOCs in particular, as well as acetonitrile, were markedly increased. The increase in $\mathrm{CO}, \mathrm{NO}_{\mathrm{x}}$, and black carbon (BC) concentrations was also observed during this time (Kanaya et al., 2008).

The ion signal at M31 was assigned to formaldehyde (Fig. 5a); however, we have reported that interference with this signal by fragments derived from methyl hydroperoxide and alcohols is not negligible in ambient air measurements. Therefore, the PTR-MS-derived concentrations of formaldehyde were corrected (Inomata et al., 2008). The consistency of the corrected values was checked by comparison with data obtained by multi-axis differential optical absorption spectroscopy (MAX-DOAS) (Inomata et al., 2008). The mixing ratios typically varied from 0 to $5 \mathrm{ppbv}$, except during the night of 12 June.

The ion signal at M45 was assigned to acetaldehyde (Fig. 5a). The observed mixing ratios of acetaldehyde were 

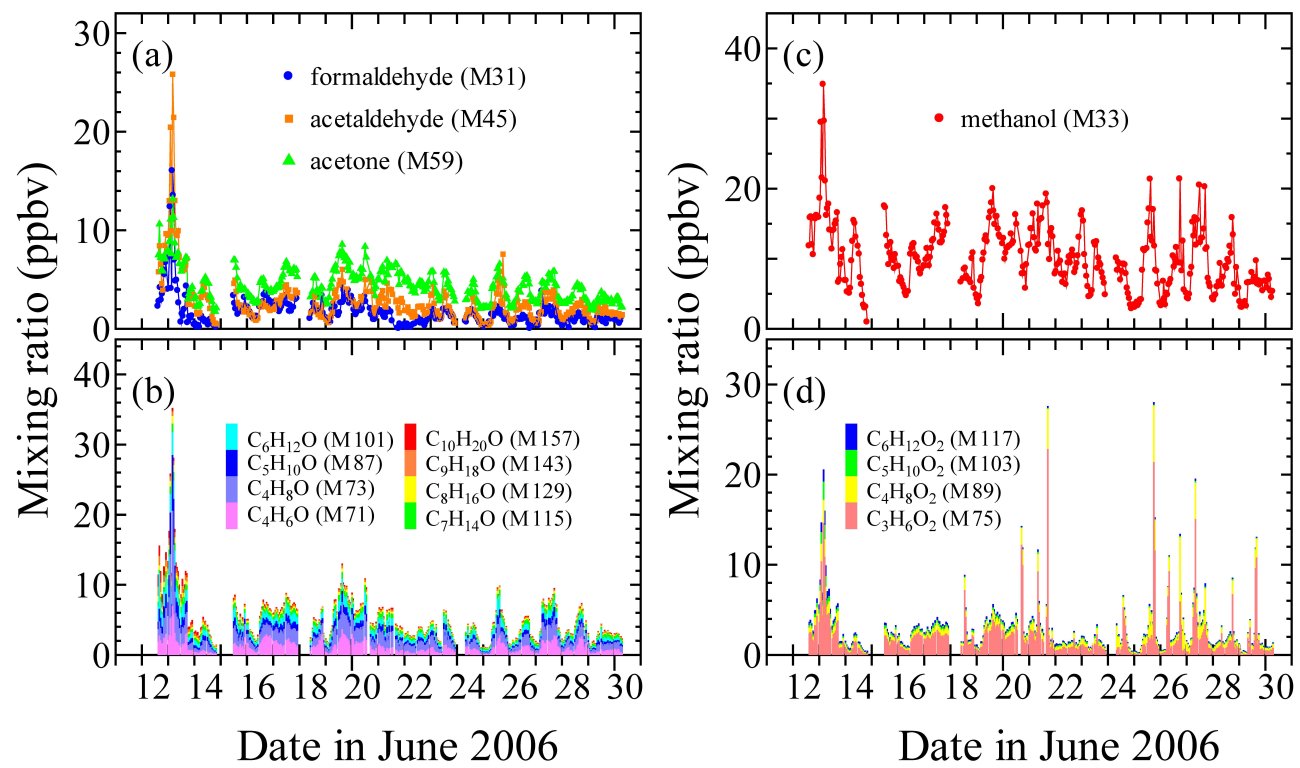

Fig. 5. Temporal variations of mixing ratios for OVOCs: (a) and (b) ketones/aldehydes, (c) methanol, and (d) $\mathrm{C}_{n} \mathrm{H}_{2 n} \mathrm{O}_{2}$ (acids/formates/acetates/hydroxyketones/hydroxyaldehydes). Hourly averaged PTR-MS data are shown.

usually higher than those of formaldehyde, approximately 1.6 times those of formaldehyde during the whole observation period. The mixing ratios of formaldehyde are generally higher than those of acetaldehyde at urban sites (Shao et al., 2009; Feng et al., 2005; Komazaki et al., 1999), suburban sites (de Gouw et al., 2009), and rural sites (Shepson et al., 1991). Formaldehyde and acetaldehyde originate from both primary and secondary sources. If the predominant source of both aldehydes is photochemical production, the formaldehyde/acetaldehyde (F/A) ratio can be expected to be higher than 1 , which is the case at rural sites $(F / A \approx 3-4)$ (Shepson et al., 1991). The low F/A ratio (F/A $\approx 0.6)$ in the present study suggests a primary emission source for acetaldehyde. Recently, Karl et al. (2007), for example, reported emission ratios of reactive NMVOCs obtained by fires in tropical forests, and they found that the contribution of OVOCs was higher than previously assumed for modeling purposes (Andreae and Merlet, 2001).

The ion signal at M59 was attributed to acetone and propanal (Fig. 5a). For the purposes of studying atmospheric chemistry, the signal at M59 can be regarded as a measurement of acetone because studies have shown that the contribution from propanal is typically small $(0-10 \%)$ (de Gouw and Warneke, 2007). The mixing ratios typically varied from 2 to $9 \mathrm{ppbv}$, except during the night of 12 June. Saturated ketones/aldehydes $\left(\mathrm{C}_{n} \mathrm{H}_{2 n} \mathrm{O}, \mathrm{n} \leq 10\right)$ were detected by PTR-MS and were quantified by means of Eq. (1) (Fig. 5b). The ion signal at M71, which was attributed to MVK and MACR, is shown in Fig. $5 \mathrm{~b}$ as an example of unsaturated ketones/aldehydes. As mentioned above, pentenes would give an ion signal at M71. However, the total mixing ratios of 1- pentene, cis-2-pentene, trans-2-pentene, 3-methyl-1-butene, and 2-methyl-2-butene obtained by GC-FID ranged from 5 to $26 \mathrm{pptv}$, and these values were very small compared with the mixing ratios $(\sim 1 \mathrm{ppbv})$ calculated from the observed ion signal at $m / z, 71$.

The ion signal at M33 was attributed to methanol (Fig. 5c). The amount of methanol was large compared with the amounts of acetaldehyde and acetone. This result is similar to that observed at urban areas (Liu et al., 2009; Warneke et al., 2007) and near tropical forest fires (Karl et al., 2007). The mixing ratios typically varied from 1 to $21 \mathrm{ppbv}$, except during the night of 12 June. In Fig. 5d, temporal variations of $\mathrm{C}_{n} \mathrm{H}_{2 n} \mathrm{O}_{2}$, which were attributed to acids, formates, acetates, hydroxyketones, and hydroxyaldehydes, are shown. Sharp peaks were observed in the morning, in the evening, or at both times, which suggests primary emission sources for these VOCs.

Similar day-to-day variations were observed for these OVOCs, except for $\mathrm{C}_{n} \mathrm{H}_{2 n} \mathrm{O}_{2}$, which showed sharp peaks. High concentrations for most of the OVOCs were observed during the night of 12 June. Overall mean concentrations of these OVOCs during the entire period were $\sim 30 \mathrm{ppbv}$, which is approximately 5 times those of NMHCs determined by GC-FID ( $\sim 6 \mathrm{ppbv})$. In addition to the ion peaks for OVOCs discussed above, ion signals at M47 and M61 were rather strong, as shown in the mass spectrum (Fig. 1). M47 can be assigned to formic acid and ethanol, whereas M61 can be attributed to acetic acid, methyl formate, glycolaldehyde, and fragments from acetates. Further work is necessary to identify and quantify isobaric molecules. 


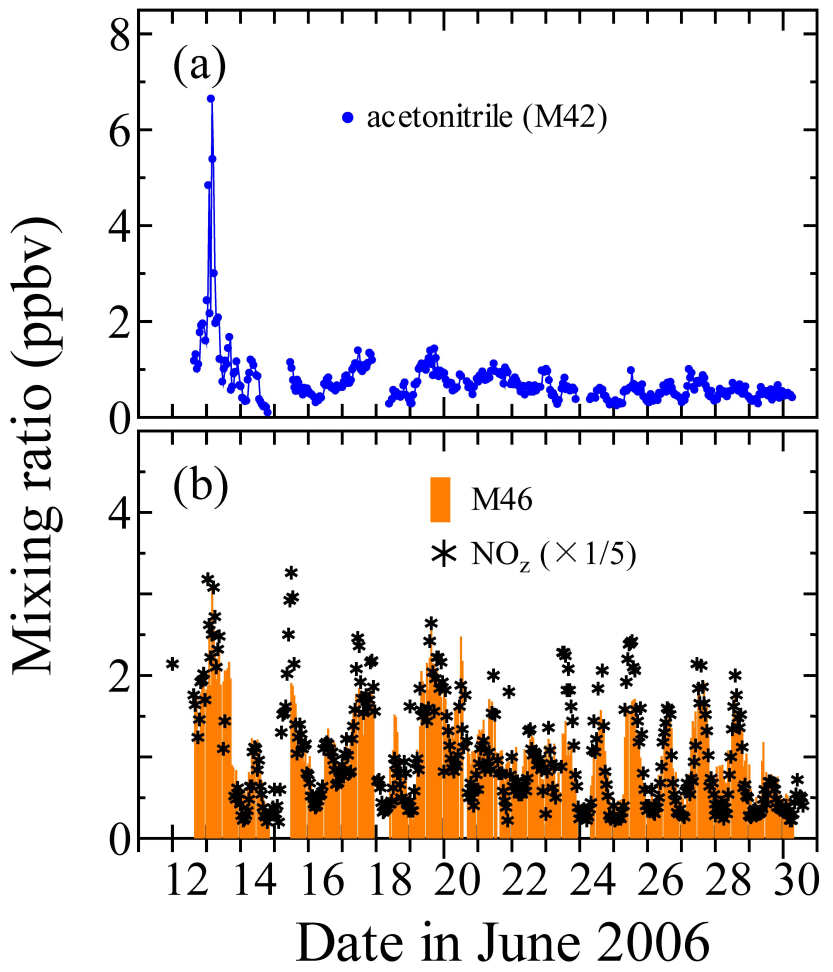

Fig. 6. Temporal variations of mixing ratios for nitrogen-containing VOCs: (a) acetonitrile, (b) M46 and $\mathrm{NO}_{\mathrm{z}}\left(=\mathrm{NO}_{\mathrm{y}}-\mathrm{NO}_{\mathrm{x}}\right)$. Hourly averaged PTR-MS and $\mathrm{NO}_{\mathrm{Z}}$ data are shown.

\subsubsection{Nitrogen-containing species}

The ion signal at M42 was assigned to acetonitrile. Temporal variations of mixing ratios for acetonitrile are shown in Fig. 6a. The mixing ratios increased during the episode of high NMVOCs concentrations (night of 12 June). Because acetonitrile is thought to be primarily emitted from burning vegetation and because it is long lived ( $\tau \approx 900$ days), it is used as a marker for biomass burning (Karl et al., 2007). The statistics of the mixing ratios were summarized in Table 4. The mean concentrations for acetonitrile during the entire period was $\sim 1 \mathrm{ppbv}$.

Using a custom-built PTR-TOFMS instrument, Aoki et al. (2007) found that $C_{1}-C_{5}$ alkyl nitrates give significant ion signals at $m / z 46$ for $\mathrm{NO}_{2}^{+}$as a fragment ion. In Fig. 6b, the temporal variation of the mixing ratio for fragment $\mathrm{NO}_{2}^{+}$is shown; the variation was calculated using the ion signal at $m / z$ 46. For reference, the variation of $\mathrm{NO}_{\mathrm{z}}\left(=\mathrm{NO}_{\mathrm{y}}-\mathrm{NO}_{\mathrm{x}}\right)$ is also shown in the figure. The day-to-day variations for $\mathrm{M} 46$ and $\mathrm{NO}_{\mathrm{z}}$ were similar, and the mixing ratio of $\mathrm{NO}_{\mathrm{z}}$ was approximately 5 times the mixing ratio obtained from the intensity of M46.

Figure 7a shows scatterplots of mixing ratios calculated from M78 and M46. M78 corresponds to protonated methyl nitrate $\left(\mathrm{CH}_{3} \mathrm{ONO}_{2} \mathrm{H}^{+}\right)$. The relationship between $\mathrm{M} 46$ and M78 was linear, and the best-fit line obtained by means of
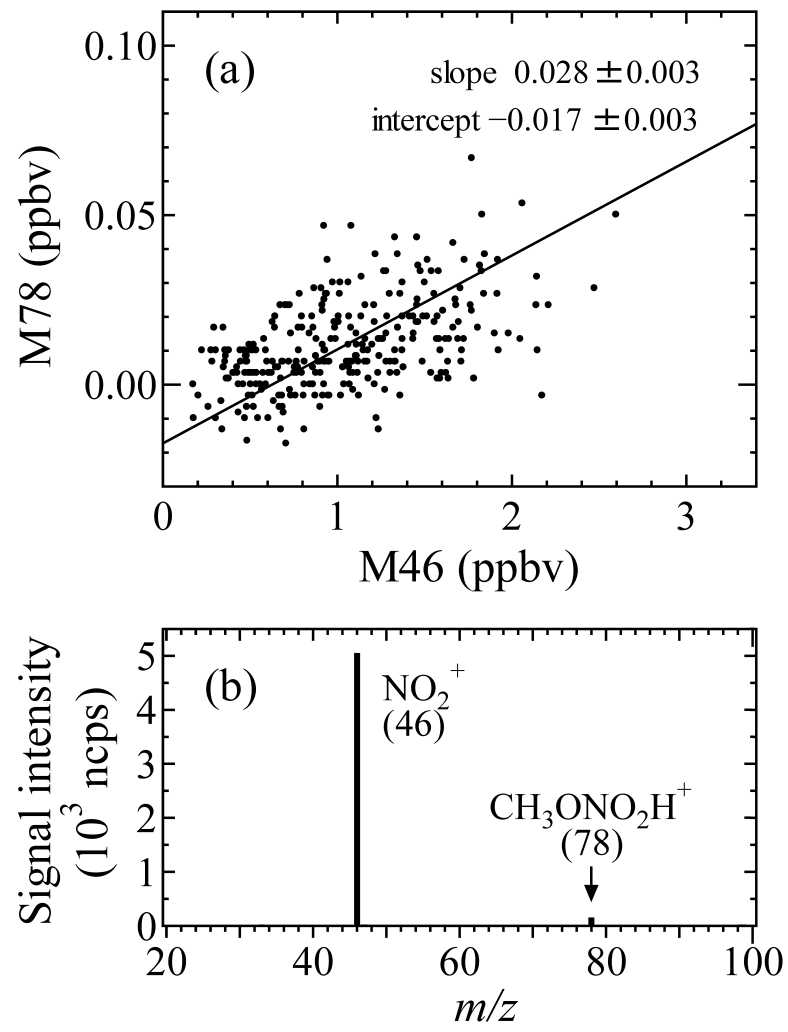

Fig. 7. (a) Scatterplots of M46 versus M78 observed during the campaign. A best-fit line obtained by the RMA regression method is shown as a solid line. (b) A reference mass spectrum of methyl nitrate.

RMA regression had a slope of $0.028 \pm 0.003$. A reference mass spectrum of methyl nitrate showed that the ratio of the ion signal at M78 to that at M46 was $\sim 0.03$ (Fig. 7 b), which was consistent with the slope obtained in Fig. 7a. This result suggests that the ion signal at $m / z 46$ could be attributed mainly to the fragment ion from protonated methyl nitrate, although there was some offset of the $\mathrm{NO}_{2}^{+}$ion that was probably caused by other higher alkyl nitrates. On the basis of the calculated mixing ratios for $m / z, 46$ species that were mainly attributed to methyl nitrate in this study, approximately $20 \%$ of the $\mathrm{NO}_{z}$ could probably be attributed to alkyl nitrates and the rest to other nitrogen-containing compounds such as nitric acid $\left(\mathrm{HNO}_{3}\right.$ ), peroxy acyl nitrates (PANs), and $\mathrm{N}_{2} \mathrm{O}_{5}$.

\section{5 $\Delta \mathrm{NMVOCs} / \triangle \mathrm{CO}$ ratios in biomass burning plumes}

As mentioned in Sect. 3.4, an episode of high NMVOCs concentrations was observed during the night of 12 June. Along with data for $\mathrm{O}_{3}, \mathrm{CO}, \mathrm{NO}_{\mathrm{x}}$, and $\mathrm{NO}_{\mathrm{z}}, 10$-min averaged PTRMS data for several NMVOCs are plotted in Fig. 8: methanol (M33), formaldehyde (M31), acetaldehyde (M45), acetone (M59), MEK/butanals (M73), acetonitrile (M42), benzene (M79*), toluene (M93*), $\Sigma \mathrm{C}_{8}$ benzenes (M107), and $\Sigma \mathrm{C}_{9}$ benzenes (M121). The high concentrations likely stem from 

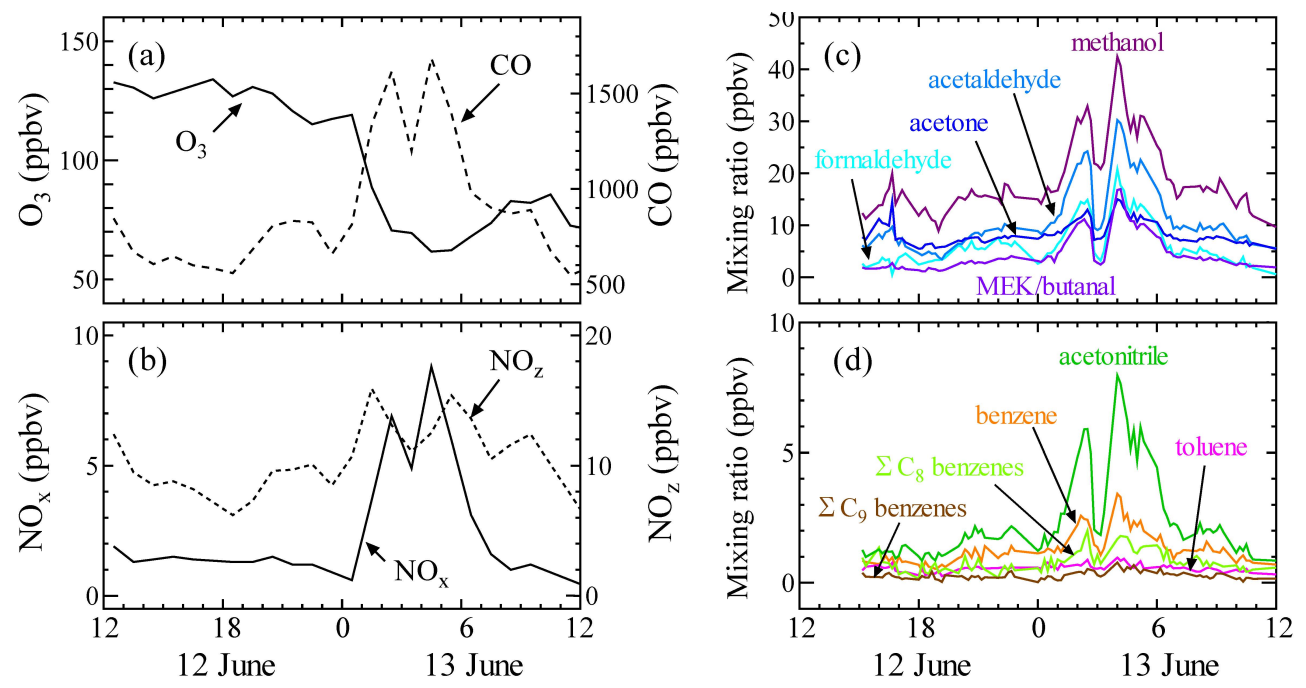

Fig. 8. Temporal variations of mixing ratios of $\mathrm{O}_{3}, \mathrm{CO}, \mathrm{NO}_{\mathrm{x}}, \mathrm{NO}_{\mathrm{z}}$, and several NMVOCs during the night of 12 June. Ten-minute averaged PTR-MS data are shown for the VOCs.

Table 5. $\Delta \mathrm{NMVOCs} / \triangle \mathrm{CO}(\mathrm{pptv} / \mathrm{ppbv})$ ratios during the biomass burning plume.

\begin{tabular}{lcccc}
\hline NMVOC & \multicolumn{2}{c}{ This work $^{\mathrm{a}}$} & $\begin{array}{c}\text { Andreae and Merlet (2001) } \\
\text { Agricultural residues }\end{array}$ & $\begin{array}{c}\text { Karl et al. (2007) }^{\mathrm{b}} \\
\text { Fires in tropical forest fuels }\end{array}$ \\
\hline Acetonitrile & 42 & $4.8 \pm 1.1$ & 1.3 & $2.5 \pm 0.8$ \\
Formaldehyde & 31 & $11.9 \pm 3.0$ & 14 & $11 \pm 10$ \\
Acetaldehyde & 45 & $17.6 \pm 3.5$ & 4.5 & $11 \pm 7$ \\
\hline Methylethylketone & 73 & $9.7 \pm 2.4$ & 1.9 & $3.0 \pm 2.6$ \\
Butanal & & & 0.1 & $2.3 \pm 2.0$ \\
\hline
\end{tabular}

a Error limits represent 95\% confidence levels. Data from 18:00 CST on 12 June to 12:00 CST on 13 June.

b Values from field experiments.

significant open biomass burning of crop residues as discussed elsewhere (Li et al., 2008; Suthawaree et al., 2010; Yamaji et al., 2009). After harvest, crop residue is either directly returned to agriculture fields as fertilizer, burned in the field, or used as biofuel (Yamaji et al., 2009). The observation site was located in the fire spot cluster spreading over $800 \mathrm{~km}$ (longitude) $\times 400 \mathrm{~km}$ (latitude) during the first half of the campaign, displayed by Suthawaree et al. (2010).

During the episode, the mixing ratio of $\mathrm{CO}$ increased from $500 \mathrm{ppbv}$ to $1500 \mathrm{ppbv}$; the $\mathrm{NO}_{\mathrm{x}}$ mixing ratio also increased, and the temporal variation of $\mathrm{NO}_{\mathrm{x}}$ was similar to that of $\mathrm{CO}$. In contrast, a decrease in $\mathrm{O}_{3}$ was observed during the time when the $\mathrm{CO}$ mixing ratio was high. In addition, no significant increase of $\mathrm{NO}_{\mathrm{z}}$ was observed. These results suggest that the contribution of the secondary photochemical production was not significant and that the air masses during the episode were probably fresh. An increase in acetonitrile was clearly observed, reflecting the impact of biomass burning, likely located nearby. In addition to acetonitrile, other
OVOCs, including methanol, formaldehyde, acetaldehyde, acetone, and MEK/butanal, also showed increased mixing ratios. To obtain emission ratios of NMVOCs, the photochemical age of NMVOCs should be considered. However, because the sources of the biomass burning were likely to have been close to the observation site, an emission ratio of species A to species B can be approximated from $\Delta$ (VMRA) $/ \Delta(\mathrm{VMR}-\mathrm{B})$.

Scatterplots of $\mathrm{CO}$ mixing ratios versus mixing ratios for acetonitrile and OVOCs are shown in Fig. 9. Suthawaree et al. (2010) suggested that the major pollution source changed after 16 June, as indicated by $\Delta \mathrm{CH}_{3} \mathrm{Cl} / \Delta \mathrm{CO}$ ratios. Therefore, we obtained the $\triangle \mathrm{NMVOC} / \triangle \mathrm{CO}$ ratios from the slope of the scatterplots in two periods: (1) 18:00 CST on 12 June to 12:00 CST on 13 June, referred to as "biomass burning plume (BB plume)" and (2) 16-23 June, referred to as "without BB plume." The data for 24-28 June were excluded from the without BB plume data because substantial diurnal variations that depended mainly on local photochemistry were 

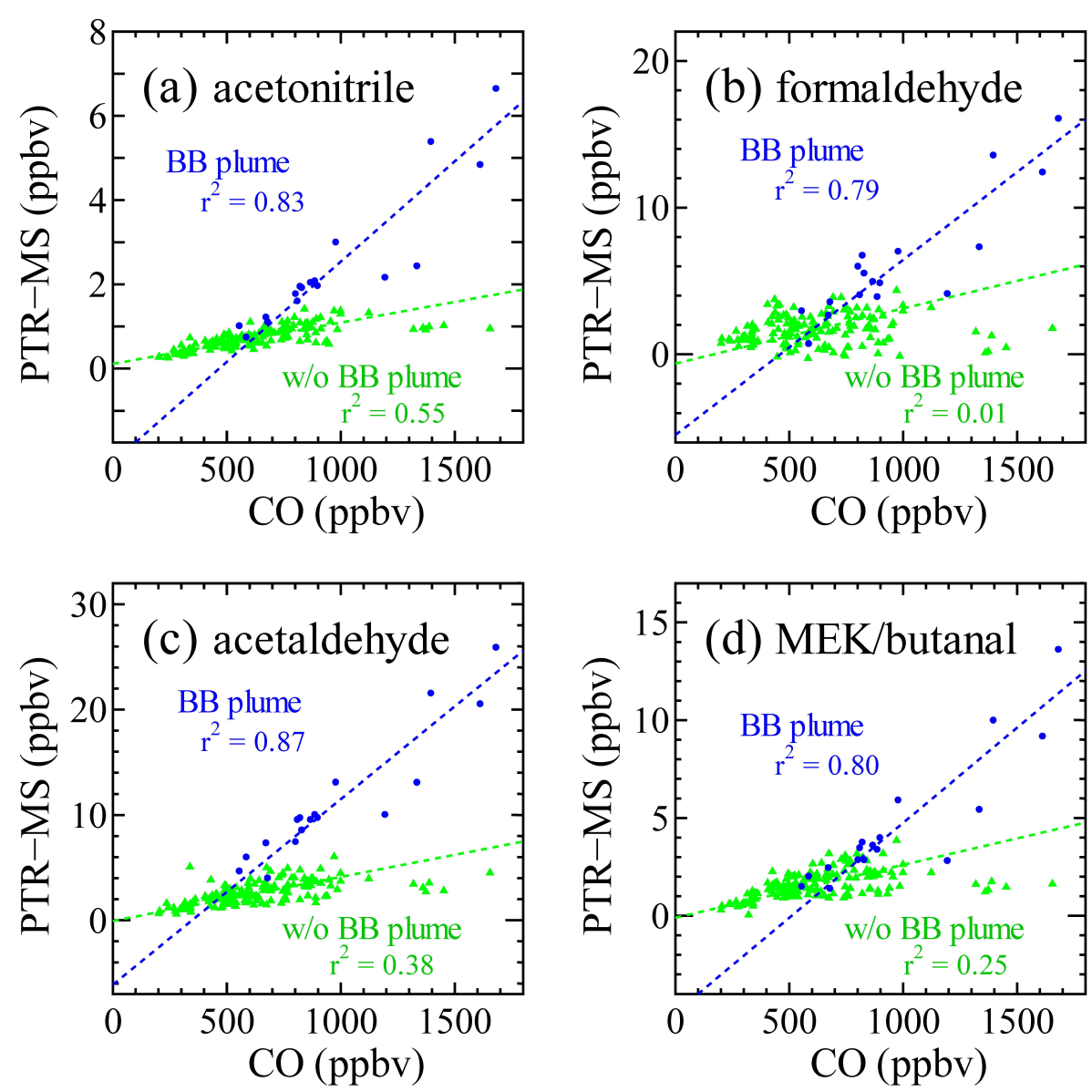

Fig. 9. Scatterplots of CO versus (a) acetonitrile, (b) formaldehyde, (c) acetaldehyde, and (d) MEK/butanal in the biomass burning plume (blue dots, $n=17$ ) and without biomass burning plume (green triangles, $n=161$ ). The best-fit lines obtained by RMA regression are shown as dashed lines.

observed every day during 24-28 June. As shown in Fig. 9, the mixing ratio of $\mathrm{CO}$ varied up to $1500 \mathrm{ppbv}$ during both periods; however, the increase in the mixing ratios of acetonitrile, formaldehyde, acetaldehyde, and MEK/butanal relative to the mixing ratio of $\mathrm{CO}$ was substantially higher during the $\mathrm{BB}$ plume than without $\mathrm{BB}$ plume.

The $\triangle \mathrm{NMVOCs} / \triangle \mathrm{CO}$ ratios obtained during the biomass burning are listed in Table 5. For comparison, $\triangle \mathrm{NMVOCs} / \triangle \mathrm{CO}$ emission ratios from biomass burning of agricultural residues reviewed by Andreae and Merlet (2001) are also tabulated. The $\Delta$ (formaldehyde) $/ \Delta \mathrm{CO}$ ratio during the BB plume was similar to the value reported in the review, whereas the observed $\triangle \mathrm{NMVOC} / \triangle \mathrm{CO}$ ratios for acetonitrile, acetaldehyde, and MEK/butanal were higher than the emission ratios reported in the review. Recently, Karl et al. (2007) reported the emission ratios of NMVOCs to $\mathrm{CO}$ from fires in tropical forest fuels obtained during the TROFFEE (Tropical Fire and Forest Emission Experiment) campaign carried out in Brazil; these ratios are also listed in Table 5. The $\Delta$ NMVOCs/ $\triangle \mathrm{CO}$ ratios for formaldehyde and acetaldehyde were comparable to those reported by Karl et al. (2007), and the values for acetonitrile and MEK/butanal were slightly higher than those reported by Karl et al. (2007).

As mentioned above, the mixing ratio of $\mathrm{CO}$ increased to $1500 \mathrm{ppbv}$ even without BB plume, when the fire spot faded or the trajectory of the air mass did not pass over the fire location (Suthawaree et al., 2010). This result suggests that the air at the observatory was influenced by polluted air masses from other sources. In Table 6 , the $\Delta$ OVOCs $/ \Delta C O$ ratios without $\mathrm{BB}$ plume are compared with $\Delta \mathrm{OVOCs} / \Delta \mathrm{CO}$ emission ratios observed at urban sites in the United States (Warneke et al., 2007). We did not consider the photochemical age of any of the OVOCs. The $\Delta$ OVOCs $/ \triangle \mathrm{CO}$ ratios were comparable to or larger than the emission ratios at urban sites (Warneke, et al., 2007), which suggests that the photochemical production of OVOCs or the emission ratios were higher at the summit of Mount Tai than in the urban sites (Boston/New York) of the United States east coast. 
Table 6. $\triangle \mathrm{OVOCs} / \Delta \mathrm{CO}(\mathrm{pptv} / \mathrm{ppbv})$ ratios without biomass burning plume.

\begin{tabular}{llll}
\hline OVOC & \multicolumn{2}{c}{ This work $^{\mathrm{a}}$} & $\begin{array}{l}\text { Warneke et al. } \\
(2007) \\
\text { Boston/New York }\end{array}$ \\
& $m / z$ & Mount Tai & 5.0 \\
\hline $\begin{array}{l}\text { Acetaldehyde } \\
\text { Acetone }\end{array}$ & 45 & $4.2 \pm 0.5$ & 5.8 \\
$\begin{array}{l}\text { Propanal } \\
\text { Methylethylketone }\end{array}$ & 59 & $5.0 \pm 0.6$ & - \\
Butanal & 73 & $2.7 \pm 0.4$ & 2.0 \\
\hline Methanol & 33 & $14 \pm 2$ & - \\
\hline
\end{tabular}

a Error limits represent $95 \%$ confidence levels.

\section{Summary}

NMVOCs were measured by means of PTR-MS during an intensive field campaign at the summit of Mount Tai, China, in June 2006 using the instrument's scan mode. As far as we know, this is the first measurement of NMVOCs by PTR-MS in China. Ion peaks were detected up to $m / z 160$ and were attributed to OVOCs (e.g., alcohols, aldehydes/ketones, formates/acetates), NMHCs (e.g., biogenic VOCs, aromatics), and nitrogen-containing species (e.g., acetonitrile). We calibrated eleven NMVOCs by using a standard gas mixture, and we calculated the mixing ratios of other NMVOCs on the basis of the rate constant of the protonation reaction. The PTRMS-derived concentrations for several NMHCs were compared with concentrations obtained by GC-FID, and the results suggested that the PTR-MS-derived concentrations for isoprene, benzene, and toluene tended to be overestimated owing to interference from other species, including fragment ions.

Diurnal variations were observed every day for 24-28 June. The diurnal variation pattern of the aldehydes/ketones showed behavior indicating a combination of primarily emitted species (e.g., $\mathrm{NO}_{\mathrm{x}}$ ) and photochemically produced species (e.g., $\mathrm{NO}_{\mathrm{z}}$ ). The mixing ratio of OVOCs quantified by PTR-MS averaged about $30 \mathrm{ppbv}$ during the observation period; OVOCs were the predominant NMVOCs.

An episode of high NMVOCs concentrations was observed during the night of 12 June, owing to biomass burning. In addition to acetonitrile, OVOCs rather than aromatics showed increased mixing ratios during the episode. The ratios of $\Delta$ (acetonitrile), $\Delta$ (formaldehyde), $\Delta$ (acetaldehyde), and $\Delta$ (MEK/butanal) to $\Delta \mathrm{CO}$ during the biomass burning plume were substantially higher than the ratios without the biomass burning plume. The $\Delta$ (formaldehyde) $/ \Delta \mathrm{CO}$ ratio during the biomass burning plume was similar to the emission ratios from biomass burning of agricultural residues reviewed by Andreae and Merlet (2001), whereas the $\triangle \mathrm{NMVOCs} / \triangle \mathrm{CO}$ ratios for acetonitrile, acetaldehyde, and MEK/butanal were larger than the reviewed emission ratios. After 16 June, when either the fire spot had faded or the trajectory of the air mass no longer passed over the fire spot, the $\triangle \mathrm{OVOCs} / \triangle \mathrm{CO}$ ratios were comparable to or larger than emission ratios determined for urban sites in the United States. These results suggest that the photochemical production of OVOCs or the emission ratios were higher at the summit of Mount Tai than in the urban area (Boston/New York) of the United States east coast.

\section{Supplementary material related to this article is available online at: http://www.atmos-chem-phys.net/10/7085/2010/ acp-10-7085-2010-supplement.pdf.}

Acknowledgements. We are grateful to participating members in the field campaign at Mount Tai in China, especially to Kazuhiro Okuzawa (Hokkaido University) and Hitoshi Irie (FRCGC/JAMSTEC) for their help with operation at Mount Tai and to Kazuyo Yamaji (FRCGC/JAMSTEC) for valuable discussions. We thank Miori Ohno (NIES) for her help with PTR-MS data processing and Sohiko Kameyama (NIES) for his help in the calibration experiments with PTR-MS. Funding support for this study was provided by the Global Environment Research Fund of the Ministry of the Environment, Japan (B-051 and S-7-1).

Edited by: L. Molina

\section{References}

Akimoto, H.: Overview of Mount Tai Experiment 2006 (MTX2006), Atmos. Chem. Phys. Discuss., in preparation, 2010.

Andreae, M. O. and Merlet, P.: Emission of trace gases and aerosols from biomass burning, Global Biochem. Cy., 15, 955-966, 2001.

Aoki, N., Inomata, S., and Tanimoto, $\mathrm{H}$.: Detection of $\mathrm{C}_{1}-\mathrm{C}_{5}$ alkyl nitrates by proton transfer reaction time-of-flight mass spectrometry, Int. J. Mass Spectrom. 263, 12-21, 2007.

Atkinson, R.: Atmospheric chemistry of $\mathrm{VOCs}$ and $\mathrm{NO}_{\mathrm{x}}$, Atmos. Environ., 34, 2063-2101, 2000.

Ayers, G. P.: Comment on regression analysis of air quality data, Atmos. Environ. 35, 2423-2425, 2001.

Barletta, B., Meinardi, S., Rowland, F. S., Chan, C.-Y., Wang, X., Zou, S., Chan, L. Y., and Blake, D. R.: Volatile organic compounds in 43 Chinese cities, Atmos. Environ., 39, 5979-5990, 2005.

Blake, R. S., Monks, P. S., and Ellis, A. M.: Proton-transfer reaction mass spectrometry, Chem. Rev. 109, 861-896, 2009.

Carmichael, G. R., Tang Y. Kurata, G., Uno, I., Streets, D. G., Thongboonchoo, N., Woo, J.-H., Guttikunda, S., White, A., Wang, T., R., Blake, D. R., Atlas, E., Fried, A., Potter, B., Avery, M. A., Sachse, G. W., Sandholm, S. T., Kondo, Y., Talbot, R. W., Bandy, A., Thorton, D., and Clarke, A. D.: Evaluating regional emission estimates using the TRACE-P observations, J. Geophys. Res. 108, 8810, doi:10.1029/2002JD003116, 2003 a.

Carmichael, G. R., Tang Y. Kurata, G., Uno, I., Streets, D., Woo, J.-H., Huang, H., Yienger, J., Leger, B., Shetter, R., Blake, 
D., Atlas, E., Fried, A., Apel, E., Eisele, F., Cantrell, C., Avery, M., Barrick, J., Sachse, G., Brune, W., Sandholm, S., Kondo, Y., Singh, H., Talbot, R., Bandy, A., Thorton, D., Clarke, A., and Heikes, B.: Regional-scale chemical transport modeling in support of the analysis of observations obtained during the TRACE-P experiment, J. Geophys. Res., 108, 8823, doi:10.1029/2002JD003117, 2003b.

Carter, W. P. L. and Atkinson, R.: Computer modeling study of incremental hydrocarbon reactivity, Environ. Sci. Technol. 23, 864-880, 1989.

Chan, L.-Y., Chu, K.-W., Zou, S.-C., Chan, C.-Y., Wang, X.M., Barletta, B., Blake, D. R., Guo, H., and Tsai, W.-Y., Characteristics of nonmethane hydrocarbons (NMHCs) in industrial, industrial-urban, and industrial-suburban atmospheres of the Pearl River Delta (PRD) region of south China, J. Geophys. Res. 111, D11304, doi:10.1029/2005JD006481, 2006.

Christian, T. J., Kleiss, B., Yokelson, R. J., Holzinger, R., Crutzen, P. J., Hao, W. M., Shirai, T., and Blake, D. R.: Comprehensive laboratory measurements of biomass-burning emissions: 2. First intercomparison of open-path FTIR, PTRMS, and GC-MS/FID/ECD, J. Geophys. Res. 109, D02311, doi:10.1029/2003JD003874, 2004.

de Gouw, J. A., Goldan, P. D., Warneke, C., Kuster, W. C., Roberts, J. M., Marchewka, M., Bertman, S. B., Pszenny, A. A. P., and Keene, W. C.: Validation of proton transfer reactionmass spectrometry (PTR-MS) measurements of gas-phase organic compounds in the atmosphere during the New England Air Quality Study (NEAQS) in 2002, J. Geophys. Res. 108, 4682, doi:10.1029/2003JD003863, 2003.

de Gouw, J. and Warneke, C.: Measurements of volatile organic compounds in the earth's atmosphere using proton-transferreaction mass spectrometry, Mass Spectrom. Rev., 26, 223-257, 2007.

de Gouw, J. A., Welsh-Bon, D., Warneke, C., Kuster, W. C., Alexander, L., Baker, A. K., Beyersdorf, A. J., Blake, D. R., Canagaratna, M., Celada, A. T., Huey, L. G., Junkermann, W., Onasch, T. B., Salcido, A., Sjostedt, S. J., Sullivan, A. P., Tanner, D. J., Vargas, O, Weber, R. J., Worsnop, D. R., Yu, X. Y., and Zaveri, R.: Emission and chemistry of organic carbon in the gas and aerosol phase at a sub-urban site near Mexico City in March 2006 during the MILAGRO study, Atmos. Chem. Phys., 9, 3425-3442, doi:10.5194/acp-9-3425-2009, 2009.

Feng, Y., Wen, S., Chen, Y., Wang, X., Lü, H., Bi, X., Sheng, G., and Fu, J.: Ambient levels of carbonyl compounds and their sources in Guangzhou, China, Atmos. Environ. 39, 1789-1800, 2005.

Finlayson-Pitts, B. J. and Pitts, Jr., J. M.: Chemistry of the upper and lower atmosphere, Academic Press, New York, USA, 2000.

Fu, P. Q., Kawamura, K., Pochanart, P., Tanimoto, H., Kanaya, Y., and Wang, Z.F.: Summertime contributions of isoprene, monoterpenes, and sesquiterpene oxidation to the formation of secondary organic aerosol in the troposphere over Mt. Tai, Central East China during MTX2006, Atmos. Chem. Phys. Discuss., 9, 16941-16972, doi:10.5194/acpd-9-16941-2009, 2009,

Gao, J., Wang, T., Ding, A., and Liu, C.: Observational study of ozone and carbon monoxide at the summit of mount Tai $(1534 \mathrm{~m}$ a.s.1.) in central-eastern China, Atmos. Environ., 39, 4779-4791, 2005.

Geng, F., Tie, X, Xu, J., Zhou, G., Peng, L., Gao, W., Tang, X., and
Zhao, C.: Characterizations of ozone, $\mathrm{NO}_{\mathrm{x}}$, and VOCs measured in Shanghai, China, Atmos. Environ., 42, 6873-6883, 2008.

Geng, F., Zhang Q., Tie, X, Huang, M., Ma, X., Deng, Z., Yu, Q., Quan, J., and Zhao, C.: Aircraft measurements of $\mathrm{O}_{3}, \mathrm{NO}_{\mathrm{X}}, \mathrm{CO}$, VOCs, and $\mathrm{SO}_{2}$ in the Yangtze River Delta region, Atmos. Environ., 43, 584-593, 2009.

He, Y. J., Uno, I., Wang, Z. F., Pochanart, P., Li, J., and Akimoto, H.: Significant impact of the East Asia monsoon on ozone seasonal behavior in the boundary layer of Eastern China and the west Pacific region, Atmos. Chem. Phys. 8, 7543-7555, doi:10.5194/acp-8-7543-2008, 2008.

Hunter, E. P. L. and Lias, S. G.: Gas Phase Basicities and Proton Affinities of Molecules: An Update, J. Phys. Chem. Ref. Data 27, 413-656, 1998.

Inomata, S., Tanimoto, H., Kameyama, S., Tsunogai, U., Irie, H., Kayana, Y., and Wang, Z.: Technical Note: Determination of formaldehyde mixing ratios in air with PTR-MS: laboratory experiments and field measurements, Atmos. Chem. Phys., 8, 273284, doi:10.5194/acp-8-273-2008, 2008.

Inomata, S. and Tanimoto, H.: A deuterium-labeling study on the reproduction of hydronium ions in the PTR-MS detection of ethanol, Int. J. Mass Spectrom. 285, 95-99, 2009.

Jobson, B. T. and McCoskey, J. K.: Sample drying to improve $\mathrm{HCHO}$ measurements by PTR-MS instruments: laboratory and field measurements, Atmos. Chem. Phys. 10, 1821-1835, doi:10.5194/acp-10-1821-2010, 2010.

Kanaya, Y., Komazaki, Y., Pochanart, P., Liu, Y., Akimoto, H., Gao, J., Wang, T., and Wang, Z.: Mass concentrations of black carbon measured by four instruments in the middle of Central East China in June 2006, Atmos. Chem. Phys., 8, 7637-7649, doi:10.5194/acp-8-7637-2008, 2008.

Kanaya, Y., Pochanart, P., Liu, Y., Li, J., Tanimoto, H., Kato, S., Suthawaree, J., Inomata, S., Taketani, F., Okuzawa, K., Kawamura, K., Akimoto, H., and Wang, Z. F.: Rates and regimes of photochemical ozone production over Central East China in June 2006: a box model analysis using comprehensive measurements of ozone precursors, Atmos. Chem. Phys., 9, 7711-7723, doi:10.5194/acp-9-7711-2009, 2009.

Karl, T. G., Christian, T. J., Yokelson, R. J., Artaxo, P. A., Hao, W. M, and Guenther, A.: The tropical forest and fire emissions experiment: method evaluation of volatile organic compound emissions measured by PTR-MS, FTIR, and GC from tropical biomass burning, Atmos. Chem. Phys. 7, 5883-5897, doi:10.5194/acp-7-5883-2007, 2007.

Komazaki, Y., Hiratsuka, M., Narita, Y., Tanaka, S., and Fujita, T.: The development of an automated continuous measurement system for the monitoring of $\mathrm{HCHO}$ and $\mathrm{CH}_{3} \mathrm{CHO}$ in the atmosphere by using an annular diffusion scrubber coupled to HPLC, Fresenius J. Anal. Chem., 363, 686-695, 1999.

Lewis, A. C., Carslaw, N., Marriott, P. J., Kinghorn, R. M., Morrison, P., Lee, A. L., Bartle, K. D., and Pilling M. J.: A large pool of ozone-forming carbon compounds in urban atmosphere, Nature, 405, 778-781, 2000.

Li, J., Wang, Z., Akimoto, H., Gao, C., Pochanart, P., and Wang, X.: Modeling study of ozone seasonal cycle in lower troposphere over East Asia, J. Geophys. Res., 112, D22S25, doi:10.1029/2006JD008209, 2007.

Li, J., Wang, Z., Akimoto, H., Yamaji, K., Takigawa, M., Pochanart, P., Liu, Y., Tanimoto, H., and Kanaya, Y.: Near-ground ozone 
source attributions and outflow in central eastern China during MTX2006, Atmos. Chem. Phys. 8, 7335-7351, doi:10.5194/acp8-7335-2008, 2008.

Lindinger, W., Hansel, A., and Jordan, A.: On-line monitoring of volatile organic compounds at pptv levels by means of ProtonTransfer-Reaction Mass Spectrometry (PTR-MS): Medical applications, food control and environmental research, Int. J. Mass Spectrom. Ion Proc., 173, 191-241, 1998a.

Lindinger, W., Hansel, A., and Jordan, A.: Proton-transfer-reaction mass spectrometry (PTR-MS): on-line monitoring of volatile organic compounds at pptv levels, Chem. Soc. Rev., 27, 347-354, 1998b.

Liu, Y. Shao, M., Lu, S., Chang, C.-C., Wang, J.-L., and Chen, G.: Volatile organic compound (VOC) measurements in the Pearl River Delta (PRD) region, China, Atmos. Chem. Phys. 8, 15311545, doi:10.5194/acp-8-1531-2008, 2008.

Liu, Y., Shao, M., Kuster, W. C., Goldan, P. D., Li, X., Lu, S., and de Gouw, J. A.: Source identification of reactive hydrocarbons and oxygenated VOCs in the summertime in Beijing, Environ. Sci. Technol. 43, 75-81, 2009.

Okuzawa, K., Kawamura, K., Aggarwal, S. G., Kanaya, Y., Akimoto, H., and Wang, Z.: Measurements of gaseous and particulate semi-volatile carbonyl compounds in the atmosphere at Mt. Taishan, Atmos. Chem. Phys. Discuss., in preparation, 2010.

Pochanart, P., Kanaya, Y., Jie, L., Komazaki, Y., Akimoto, H., Liu, Y., Wang, X., and Wang, Z.: Surface ozone, carbon monoxide and black carbon over Central East China during MTX2006, Atmos. Chem. Phys. Discuss., in preparation, 2010.

Seinfeld, J. H. and Pandis, S. N.: Atmospheric chemistry and physics, John Wiley \& Sons, Inc., New York, USA, 724-743, 1998.

Shao, M., Lu, S., Liu, Y., Xie, X., Chang, C., Huang, S., and Chen, Z.: Volatile organic compounds measured in summer in Beijing and their role in ground-level ozone formation, J. Geophys. Res. 114, D00G06, doi:10.1029/2008JD010863, 2009.

Shepson, P. B., Hastie, D. R., Schiff, H. I., Polizzi, M., Bottenheim, J. W., Anlauf, K., Mackay, G. I., and Karicki, D. R.: Atmospheric concentrations and temporal variations of $\mathrm{C}_{1}-\mathrm{C}_{3}$ carbonyl compounds at two rural sites in Central Ontario, Atmos. Environ. 25A, 2001-2015, 1991.

Smith, D. and Španel, P.: Selected ion flow tube mass spectrometry (SIFT-MS) for on-line trace gas analysis, Mass Spectrom. Rev. 24, 661-700, 2005.

Song, Y., Shao, M., Liu, Y., Lu, S., Kuster, W., Goldan, P., and Xie, S.: Source apportionment of ambient volatile organic compounds in Beijing, Environ. Sci. Technol. 41, 4348-4353, 2007.

Streets, D. G., Bond, T. C., Carmichael, G. R., Fernandes, S. D., Fu, Q., He, D., Klimont, Z., Nelson, S. M., Tsai, N. Y., Wang, M. Q., Woo, J.-H., and Yarber K. F.: An inventory of gaseous and primary aerosol emissions in Asia in the year 2000, J. Geophys. Res. 108, 8809, doi:10.1029/2002JD003093, 2003.

Suthawaree, J., Kato, S., Okuzawa, K., Kanaya, Y., Pochanart, P., Akimoto, H., Wang. Z., and Kajii, Y.: Measurements of volatile organic compounds in the middle of Central East China during Mount Tai Experiment 2006 (MTX2006): observation of regional background and impact of biomass burning, Atmos. Chem. Phys., 10, 1269-1285, doi:10.5194/acp-10-1269-2010, 2010.

Tang, J. H., Chan, L. Y., Chan, C. Y., Li, Y. S., Chang, C. C., Liu, S.
C., Wu, D., and Li, Y. D.: Characteristics and diurnal variations of NMHCs at urban, suburban, and rural sites in the Pearl River Delta and a remote site in South China, Atmos. Environ., 41, 8620-8632, 2007.

Tang, J. H., Chan, L. Y., Chan, C. Y., Li, Y. S., Chang, C. C., Wang, X. M., Zhu, S. C., Barletta, B., Blake, D. R., and Wu, D.: Implications of changing urban and rural emissions on nonmethane hydrocarbons in the Pearl River Delta region of China, Atmos. Environ., 42, 3780-3794, 2008.

Vlasenko, A., Macdonald, A. M., Sjostedt, S. J., and Abbatt, J. P. D.: Formaldehyde measurements by Proton Transfer Reaction Mass Spectrometry (PTR-MS): correction for humidity effects, Atmos. Meas. Tech. Discuss. 3, 965-988, doi:10.5194/amtd-3965-2010, 2010.

Wang, Z., Li, J., Wang, X., Pochanart, P., and Akimoto, H.: Modeling of regional high ozone episode observed at two mountain sites (Mt. Tai and Huang) in east China, J. Atmos. Chem. 55, 253-272, 2006.

Warneck, P.: Chemistry of the natural atmosphere, 2nd ed., Academic Press, New York, USA, 265-270, 2000.

Warneke, C., van der Veen, C., Luxembourg, S., de Gouw, J. A., and Kok, A.: Measurements of benzene and toluene in ambient air using proton-transfer-reaction mass spectrometry: Calibration, humidity dependence, and field intercomparison, Int. J. Mass spectrom., 207, 167-182, 2001.

Warneke, C., de Gouw, J. A., Goldan, P. D., and Fall, R.: Validation of atmospheric VOC measurements by proton-transfer-reaction mass spectrometry using a gas-chromatographic preseparation method, Environ. Sci. Technol. 37, 2494-2501, 2003.

Warneke, C., McKeen, S. A., de Gouw, J. A., Goldan, P. D., Kuster, W. C., Hollway, J. S., Williams, E. J., Lerner, B. M., Parrish, D. D., Trainer, M., Fehsenfeld, F. C., Kato, S., Atlas, E. L., Baker, A., and Blake, D. R.: Determination of urban volatile organic compound emission ratios and comparison with an emissions database, J. Geophys. Res., 112, D10S47, doi:10.1029/2006JD007930, 2007.

Xie, X., Shao, M., Liu, Y. Lu, S., Chang, C.-C., and Chen, Z.-M.: Estimate of initial isoprene contribution to ozone formation potential in Beijing, China, Atmos. Environ. 42, 6000-6010, 2008.

Yamaji, K., Ohara, T., Uno, I., Kurokawa, J, Pochanart, P., and Akimoto, H.: Future prediction of surface ozone over east Asia using Models-3 Community Multiscale Air Quality Modeling System and Regional Emission Inventory in Asia, J. Geophys. Res. 113, D08306, doi:10.1029/2007JD008663, 2008.

Yamaji, K., Li, J., Uno, I., Kanaya, Y., Komazaki, Y., Pochanart, P., Liu, Y., Takigawa, M., Ohara, T., Yan, X., Wang. Z., and Akimoto, H.: Impact of open crop residual burning on air quality over Central Eastern China during the Mount Tai Experiment 2006 (MTX2006), Atmos. Chem. Phys. Discuss., 9, 22103-22141, 2009,

Zhang, J., Wang, T., Chameides, W. L., Cardelino, C., Blake, D. R., and Streets, D. G.: Source characteristics of volatile organic compounds during high ozone episodes in Hong Kong, Southern China, Atmos. Chem. Phys. 8, 4983-4496, doi:10.5194/acp-84983-2008, 2008.

Zhao, J. and Zhang, R.: Proton transfer reaction rate constants between hydronium ion $\left(\mathrm{H}_{3} \mathrm{O}^{+}\right)$and volatile organic compounds, Atmos. Environ., 38, 2177-2185, 2004. 